Sarah J. Pethybridge and Frank S. Hay

Tasmanian Institute of Agricultural Research (TIAR), University of Tasmania, Burnie, Tasmania, Australia

Paul D. Esker

University of Wisconsin-Madison, Madison, WI, USA

David H. Gent

U.S. Department of Agriculture-Agricultural

Research Service, Forage Seed and Cereal

Research Unit,

and Oregon State University, Corvallis, OR, USA
Calum R. Wilson

TIAR, University of Tasmania, New Town Research Laboratories,

New Town, Tasmania, Australia

Tim Groom

Botanical Resources Australia Pty. Ltd., Ulverstone, Tasmania, Australia

Forrest W. Nutter, Jr.

lowa State University, Ames, IA, USA

\title{
Diseases of Pyrethrum in Tasmania: Challenges and Prospects for Management
}

Pyrethrum (Tanacetum cinerariifolium (Trevir.) Sch. Bip.) is a perennial plant and member of the Asteraceae that is endemic to the Dalmatian region of the former Yugoslavia (36). Pyrethrum is cultivated commercially solely for the production of six closely related esters called pyrethrins. The plant is tufted, slender, and herbaceous, growing to a height of approximately one meter (18). Leaves are alternate and pinnately lobed/narrowly lanceolate to oblong lanceolate. The daisy-like flowers are produced at the termini of stems and consist of a cluster of 40 to 100 bisexual, yellow disk florets encircled by a ring of 18 to 22 pistillate white ray florets atop a moderately convex to subglobose receptacle (Fig. 1; 100). Disk and ray florets both possess 3 to 10 ribbed achenes located between the floret and receptacle. Involucres generally range between 12 and

Approximately $94 \%$ of the pyrethrins are produced within secretory ducts and oil glands of the achenes of the mature pyrethrum flower, with a minor percentage of oil glands and secretory ducts also found in leaves, stems, and roots (99). Pyrethrins can be separated into two groups of three ester compounds: pyrethrins I and II. The pyrethrin I fraction contains chrysanthemic acid products, including pyrethrin I, cinerin I, and jasmolin I. The pyrethrin II fraction is derived from pyrethric acid and

Corresponding author: Sarah J. Pethybridge, Tasmanian Institute of Agricultural Research (TIAR), University of Tasmania, Burnie, Tasmania, Australia; E-mail: sarah_jp@utas.edu.au

Mention of a trademark, proprietary product, or vendor does not constitute a guarantee or warranty of the product by the USDA and does not imply its approval to the exclusion of the products or vendors that may also be suitable.

doi:10.1094/PDIS-92-9-1260

(C) 2008 The American Phytopathological Society $18 \mathrm{~mm}$ in diameter $(17,18)$. made up of pyrethrin II, cinerin II, and jasmolin II $(19,27)$. Compounds within both fractions contain insecticidal properties used in household and commercial pest control products. These compounds are referred to as "knockdown" and kill agents for many arthropods, yet are of low toxicity to mammals. Pyrethrins also have the advantage over other synthetic insecticides of being rapidly broken down upon exposure to light and air, are metabolized quickly, and can be used in the production of organic farm products. Thus, natural pyrethrins are generally considered to be nonpolluting $(19,27)$.

The major areas of pyrethrum production worldwide are located in East Africa (Kenya, Rwanda, and Tanzania), Tasmania (Australia), China, and Papua New Guinea

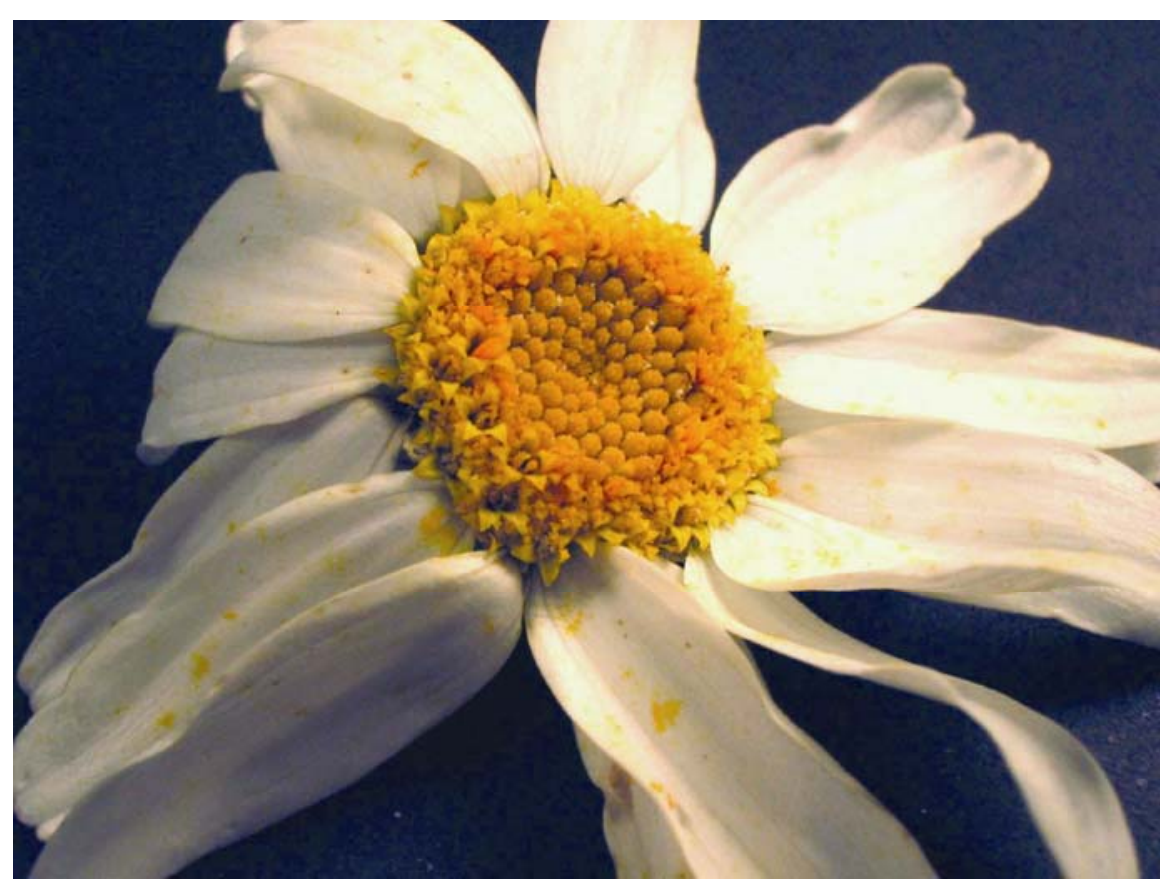

Fig. 1. Structure of a pyrethrum flower, with white ray florets surrounding yellow disk florets.

$(85,94)$. Production of pyrethrum in Kenya began in 1928, and despite some fluctuations in annual supply, Kenya is still one of the major suppliers to the world's market. Pyrethrum cultivation in Kenya is centered in four production areas: the northern and near Lake Victoria (94). Tasmania is the other major world producer and grows approximately 2,000 hectares. In Tasmania, pyrethrum is grown predominantly along the northwest coast of the island, between Deloraine $\left(41^{\circ} 31^{\prime} \mathrm{S} ; 146^{\circ} 39^{\prime} \mathrm{E}\right)$ and Table Cape $\left(40^{\circ} 56^{\prime} \mathrm{S}\right.$; $\left.145^{\circ} 43^{\prime} \mathrm{E}\right)$.

The cultivation of pyrethrum differs markedly between Tasmania and the other production areas of the world. For example, in 2001 approximately 200,000 growers were involved in pyrethrum production southern Rift Valleys, Mount Kenya, and 
in Kenya, with average individual field sizes ranging from 0.25 to 2 ha (94). The commercial lifespan of a pyrethrum crop in Kenya is 3 years, and the crop is established either by seedling or clonally produced planting material in autumn. When vegetative clones are used as planting material, first flowering occurs within 3 months of planting. When seed is planted, first flowering occurs only 12 months after seeding. Due to the small size of the pyrethrum crops and limited mechanization, flowers are hand-picked every 7 to 14 days over a 6-month period from summer to autumn. Flowers are then sun-dried before being delivered to a central processing location in Nakuru for pyrethrin extraction $(58,94)$. Production inputs such as herbicides, fungicides, and fertilizers generally are not economically viable in Kenyan pyrethrum production systems (94).

In contrast to pyrethrum production in East Africa and other low-input systems, pyrethrum production in Tasmania is highly mechanized (39). Pyrethrum production in Tasmania occurs primarily at high latitudes and low altitudes (less than $300 \mathrm{~m}$ ), and growers utilize cultivars that have been selected for synchronous flowering. Fields are planted with seed from July to September. First harvests are conducted in December and January of the following year (15 to 17 months after planting). Thereafter, harvests are conducted annually at the same time. From emergence in the first spring until the following spring, the plant is semi-dormant. Every spring thereafter, multiple stems are produced rapidly from each plant in response to increasing day length, reaching a maximum height within 12 weeks $(10,17,29)$. Agronomic performance of pyrethrum is dependent, in part, upon effective management of weeds with herbicides (80), by top-dressing with fertilizers, intensive overhead irrigation during flowering, and disease management with fungicides $(68,70,71)$. Mechanical harvesting of flowers involves swathing the crop (stems and flowers) into windrows for drying, followed by mechanically harvesting the flower heads and achenes using specialized equipment (39). Flower heads are then transported to a central location in Tasmania for pelletizing and extraction of pyrethrins.

In spite of the long history and experience of low-input pyrethrum production in other countries, there is little published information concerning the management of diseases affecting pyrethrum crops in these low-input systems. Moreover, there is little information that can be directly translated to the highly mechanized pyrethrum production systems of Tasmania, due in part to differences in agronomic practices, cultivars grown, prevalent pathogens, and profit margins. The major diseases affecting production in Tasmania are (in decreasing order of importance): ray blight caused by Phoma ligulicola Baker, Dimock \& Davis v. Arx. var. inoxydablis; Sclerotinia crown rot, usually caused by Sclerotinia minor Jagger and occasionally by S. sclerotiorum (Lib.) de Bary; Sclerotinia flower blight caused by $S$. sclerotiorum; Botrytis flower blight caused by Botrytis cinerea Pers.; root rot caused by lesion nematodes, Pratylenchus spp.; tan spot caused by Microsphaeropsis tanaceti sp. nov.; winter blight caused by Alternaria tenuissima (Nees:Fries) Wiltshire; and pink spot caused by Stemphylium botryosum Wallroth $(68,70,72,73)$. Tomato spotted wilt virus (TSWV) is also prevalent, although infected plants generally are asymptomatic (76). Ray blight is the most prevalent disease in early spring and is the primary target of spring fungicide programs $(60,62,68,71,75)$. Sclerotinia and Botrytis flower blights can be observed when the crops are flowering from early November until harvest in December, and are managed using a fungicide program during summer flowering. Sclerotinia crown rot often occurs sporadically throughout the year, regardless of crop growth stage. A fungicide-based management strategy is employed for this disease on an "as needed" basis (39). Root rot, caused by lesion nematodes, is primarily a also cause significant yield losses (32). The incidence and severity of winter blight and pink spot are highest during the winter months, when plants are semi-dormant (70). However, these diseases are not problem at seedling establishment, but can

believed to cause sufficient economic damage to warrant the implementation of additional management measures. The prevalence and incidence of TSWV in Tasmanian pyrethrum fields can vary markedly (76); however, there is no information concerning its impact on pyrethrin yield.

In Kenya, the diseases affecting pyrethrum that pose the most serious threat to production are wilt diseases (caused by a range of Fusarium spp., but primarily $F$. oxysporum Schlechtend.) (37). This disease can cause damping-off of seedlings, and in larger plants can cause partial chlorosis, necrosis, and wilting of plants, followed by plant death. The most characteristic symptom of this disease is vascular discoloration in the stem and crown that first appears as a brown discoloration that progresses into a bright pink color. The incidence and severity of pyrethrum wilt is believed to be exacerbated by injury caused by the root-knot nematode (Meloidogyne spp.). The two means of managing wilt are through the use of resistant cultivars, and avoiding planting sites that may be of high disease risk, such as those with poor water drainage (37). Wilt of pyrethrum has not been reported in Tasmania or elsewhere. Considerable reductions in pyrethrin yield in Kenya can also result from infections by $S$. minor (47), as well as true bud disease caused by Ramularia bellunensis Speg (24), and direct injury from root-knot and lesion nematodes $(3,4,57)$. True bud disease can cause considerable losses in pyrethrum production in

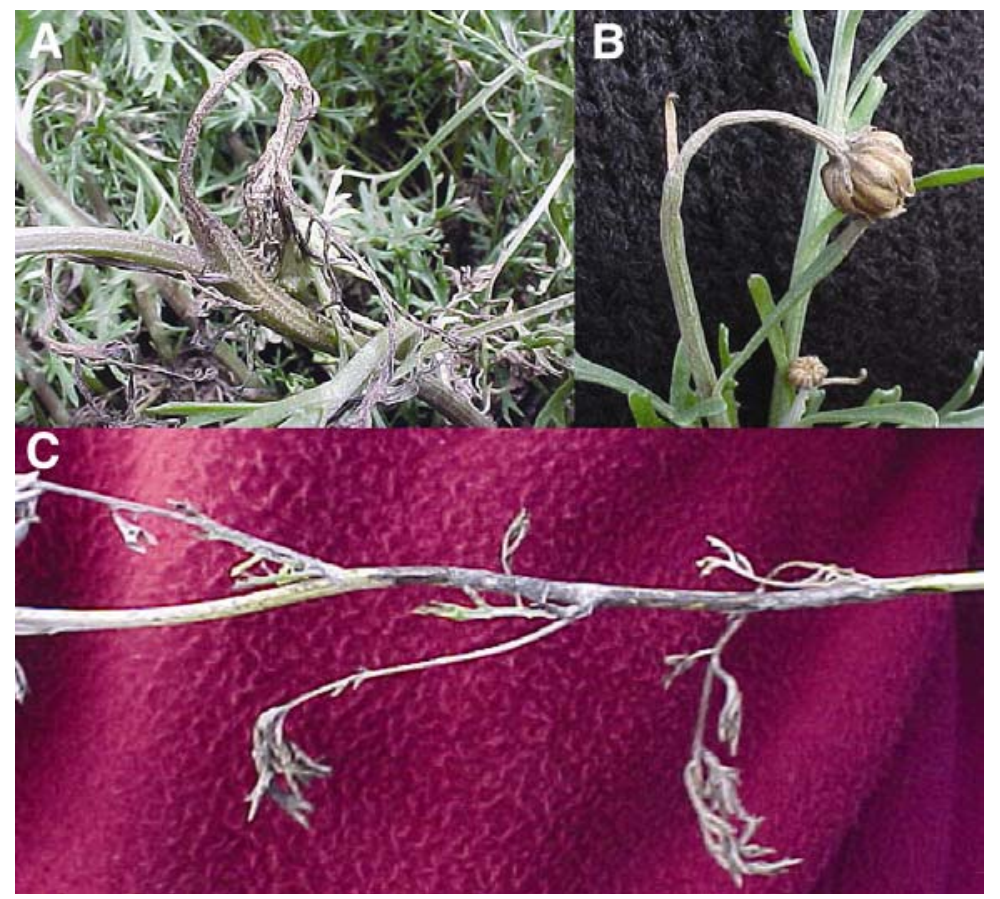

Fig. 2. A, Leaf symptoms of ray blight of pyrethrum in Tasmania, Australia, typically begin as necrotic spots and asymmetrically coalesce around the margins to eventually encompass the entire leaf surface. B, "Shepherd's crook" ray blight symptom associated with bud and flower death. C, Necrotic stem lesions initiated from leaf infections that result in girdling of the stem are also characteristic of ray blight, caused by Phoma ligulicola var. inoxydablis. 
Kenya. This disease results in symptoms nearly indistinguishable from those caused by ray blight (i.e., necrotic spots on leaves, necrotic lesions girdling stems, and diseased buds) (24). Death of buds is characteristic of another disorder found in Kenya, known as "false bud disease," which is believed to be a physiological disorder. $R$. bellunensis has not been isolated from pyrethrum in Tasmania (67). Management of this disease in Kenya is achieved solely through the use of resistant cultivars (24).

\section{Ray Blight}

Ray blight (Figs. 2 and 3) has been reported to negatively impact pyrethrum production in Tasmania $(60,68,71,75)$, Kenya $(59,81)$, and Papua New Guinea (85), although the disease generally causes minimal damage in the latter two countries. The name of this disease reflects necrosis of the ray florets of the flowers caused by the disease, and its similarity to a disease of the same common name caused by $P$. ligulicola var. ligulicola that affects garden chrysanthemum (Chrysanthemum morifolium Ram.) (7,77). Phoma ligulicola is split into two varieties based simply upon the reaction of isolates to sodium hydroxide on malt extract agar $(13,93)$. Isolates that are able to utilize sodium hydroxide, as indicated by the expression of a red pigment in the agar medium (which indicates the presence of an antibiotic metabolite 'E'), are termed $P$. ligulicola var. ligulicola. Those that do not utilize sodium hydroxide are referred to as $P$. ligulicola var. inoxydablis. To date, all isolates that cause ray blight of pyrethrum have been identified as P. ligulicola var. inoxydablis (74), whereas all isolates that cause ray blight of chrysanthemum in the United States, Germany, and Japan have been characterized as $P$. ligulicola var. ligulicola (93). P. ligulicola var. inoxydablis isolates that infect pyrethrum also differ from $P$. ligulicola var. ligulicola in the conditions required to induce sporulation in vitro (62). P. ligulicola var. inoxydablis isolates generally do not produce pycnidia on potato dextrose agar, but can be induced to form pycnidia more reliably on a modified V8 juice agar under specific environmental conditions (35). Pethybridge et al. (74) developed PCR primers from the rDNA internal transcribed spacer (ITS) region for detection of $P$. ligulicola. However, this technique cannot differentiate the two pathogen varieties.

In Tasmanian pyrethrum crops, flower symptoms of ray blight were first identified in 1995, but at that time the disease was considered to cause only minor losses (75). Ray blight symptoms often result in the death of flowers and buds, and can cause necrotic lesions that generally extend 20 to $30 \mathrm{~mm}$ from the peduncle of the unopened bud. Characteristic of this symptom is a "shepherd's crook" appearance to the diseased buds and flowers, with a clear constriction and delineation between the necrotic peduncle and the remainder of the healthy stem (Fig. 2B; 75). This symptom can be found at any time during the year when flowers are produced, but ray blight incidence is highest during the main flowering period in late spring through early summer (November to December). Since

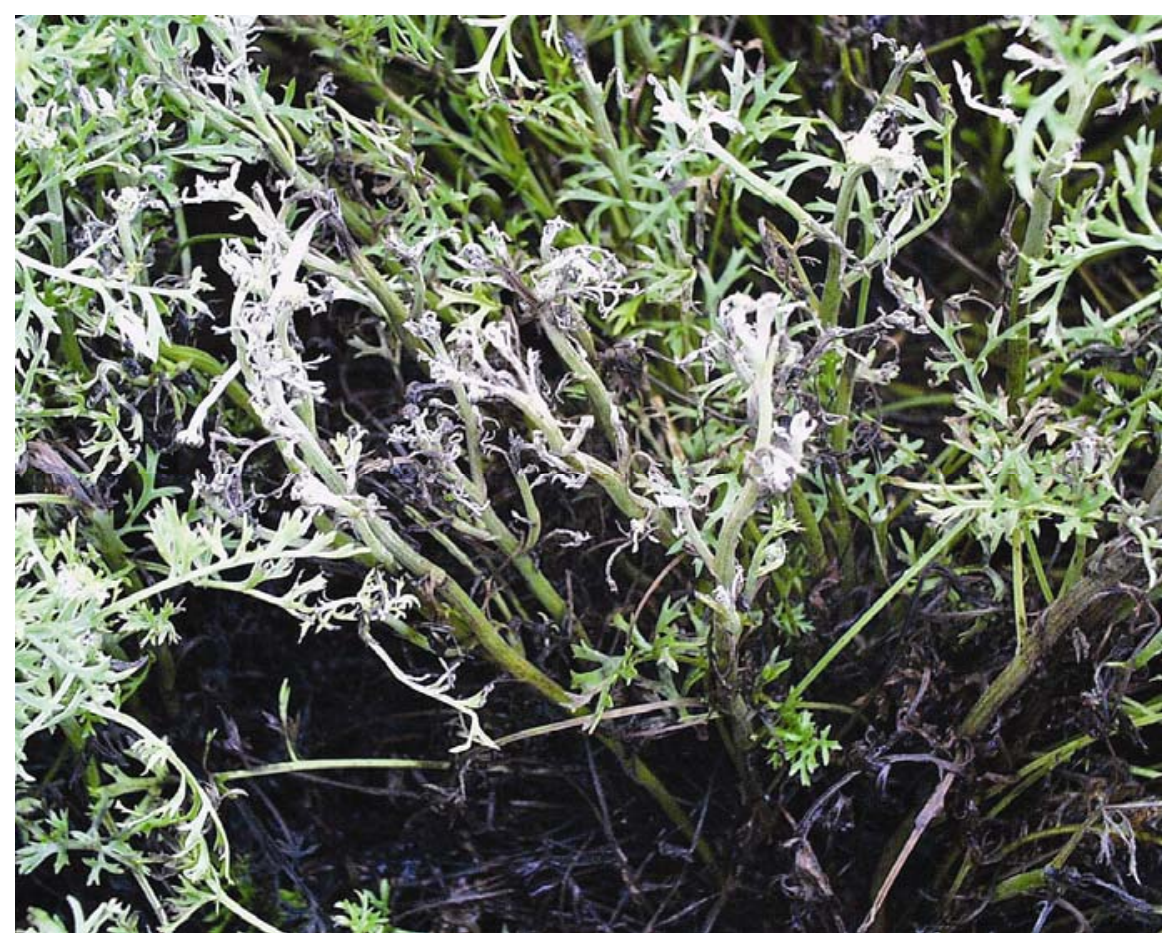

Fig. 3. Distortion of developing stems of pyrethrum plants and necrosis in the growing tips are symptoms of a severe form of ray blight caused by Phoma ligulicola var. inoxydablis in early spring in Tasmania, Australia.

1999, however, severe annual ray blight epidemics have affected the developing pyrethrum stems in early spring (62). In spring, ray blight symptoms initially begin with necrotic lesions on leaf margins (Fig. 2A). Expanding lesions coalesce to encompass entire leaves, leading to extensive defoliation and stunted plants. Dying leaves can result in necrotic lesions on the stem that often result in girdling (Fig. 2C). A severe form of ray blight can also be found on developing stems in early spring, whereby affected stems initially become chlorotic, followed by the appearance of necrotic lesions that soon become evident on shoots and developing buds. Diseased stems also appear severely distorted (Fig. 3 ; 64,67). If left unmanaged, the disease can lead to plant death. Prior to the development and application of effective ray blight management strategies, severely affected pyrethrum fields were often terminated prior to the first harvest.

Ray blight as an emerging disease in the Tasmanian industry. The severity and rapid onset of ray blight epidemics in Tasmanian pyrethrum fields presented a challenge to the pyrethrum industry and researchers. Management of the disease required rapid and accurate identification of the causal agent, identification of environmental and host risk factors contributing to epidemics, and the development of effective management strategies to minimize losses within a 2 -year period. The latter was particularly important, as the Tasmanian pyrethrum industry was (and currently remains) in an expansion phase to meet world market demand for a reliable supply of high-quality pyrethrins. Identification of the etiology of this severe form of ray blight in spring was initially hindered by the assumption that this disease primarily affected flowers and caused only minor direct losses in pyrethrum flowers. For example, Baker and Davis (6) previously reported a sudden increase in the severity of leaf and stem lesions as well as distortions in chrysanthemum stems in California caused by P. ligulicola var. ligulicola, where the disease had previously caused little damage from 1949 to 1957 (7). We can only postulate the reasons for this sudden change in types of ray blight symptoms and the marked increase in the intensity of epidemics in both pyrethrum and chrysanthemum production, including the evolution and change in the predominance of more aggressive pathotypes, the development of resistance within the pathogen populations to specific fungicides used in their respective production systems, and (or) changes in the production systems that favored disease development. In pyrethrum production in Tasmania, the increase in disease severity in spring may have been related to a change from clonal vegetative propagation and hand planting to direct seeding at higher densities, and the inadvertent use of $P$. 
ligulicola-infected seedlots that occurred 3 years prior to the first severe outbreak of ray blight.

Differences in etiology of $\boldsymbol{P}$. ligulicola on pyrethrum and chrysanthemum. The etiology of $P$. ligulicola in pyrethrum versus chrysanthemum and the relative contribution of inoculum sources for each pathosystem may differ. For example, in chrysanthemum, symptomless surface colonization of cuttings and roots by $P$. ligulicola has been demonstrated in which the fungus remains viable as an epiphyte for at least 12 weeks (20). Epiphytic colonization on 12 other ornamental species, including pyrethrum, has also been demonstrated in isolates from chrysanthemum. However, survival of the fungus on these other hosts was for no more than 8 weeks (20). Although epiphytic ability has not been demonstrated for isolates of $P$. ligulicola originating from pyrethrum, inoculum may have been introduced into pyrethrum fields via infested propagative material. In the ray blight-chrysanthemum pathosystem, Baker et al. (7) recommended that planting material be obtained from dry regions of production, as the pathogen was more likely to be present asymptomatically on plants grown in wet weather. The transport of $P$. ligulicola with asymptomatic planting material is believed to have been the primary means of long-distance dissemination of this pathogen throughout the United States (8). In contrast, seed is considered the most likely source of primary inoculum for $P$. ligulicola on pyrethrum. Pethybridge et al. (69) found all seed lots of pyrethrum tested in Tasmania were infested with P. ligulicola, with up to $28 \%$ incidence of infested seeds per lot. Since this finding, the application of foliar fungicides to pyrethrum seed crops, and as a seed treatment prior to planting, has significantly reduced the incidence of viable $P$. ligulicola in seed. Subsequent studies have demonstrated that a small proportion of infested seed can lead to seed-to-seedling transmission, but seedlings are often asymptomatic (56). Moreover, seed-toseedling transmission efficiency was found to be cultivar dependent (S. J. Pethybridge, unpublished data).

Pycnidia of $P$. ligulicola with conidia can be found readily within necrotic tissues of affected pyrethrum plants (Fig. 4; 62,75), but the teleomorph, Didymella ligulicola (Baker et al.) von Arx., has not been observed on diseased pyrethrum plants (Fig. 5; 7,77). In chrysanthemum, ascospores are believed to be responsible for long-distance dispersal of this pathogen within fields (and possibly among fields), and are the predominant inoculum source for infection of chrysanthemum flowers and buds (Fig. 4; 7,42-44). It is not known if the $P$. ligulicola genotypes that infect pyrethrum are heterothallic or homothallic. If this fungus is heterothallic, both mating types would be required for production of perithecia. The failure to detect ascospores in the field or to induce perithecia production in the laboratory suggests that only one mating type has been introduced into Tasmania (S. J. Pethybridge, unpublished data). Alternatively, the fungus may be homothallic but environmental conditions in Tasmania may not be conducive for teleomorph production. In the absence of evidence of the teleomorph, epidemics at remote locations in Tasmania have been attributed to inoculum introduced on infested seed (69).

Other inoculum sources important in the ray blight-chrysanthemum pathosystem are pseudosclerotia within the soil (12) and infected alternative compositae hosts $(21,77)$. Pseudosclerotia of $P$. ligulicola isolates causing ray blight on chrysanthemum are reported to survive in natural soil up to 30 weeks and in compost for 8 weeks. However, both the number and viability of pseudosclerotia and conidia decline rapidly (21). Although no information exists on the viability of pseudosclerotia and conidia of $P$. ligulicola isolates from pyrethrum grown in rotation with nonsusceptible hosts, the role of pseudosclerotia in the pyrethrum pathosystem is hypothesized to be minimal due to relatively long rotations ( 3 to 4 years) between pyrethrum crops in a field. The relative importance of pseudosclerotia as sources of secondary inoculum is unknown. The contribution of $P$. ligulicola-infected alternative compositae hosts to epidemics of ray blight in pyrethrum is likely to differ among isolates that cause disease in chrysanthemum versus pyrethrum. Inoculation studies have demonstrated that, unlike isolates of P. ligulicola var. ligulicola from chrysanthemum, isolates from pyrethrum are unable to infect zinnia (Zinnia elegans L.), sunflower (Helianthus annuus L.), dahlia (Dahlia variabilis Desf.), and several cultivars of crisphead lettuce (Lactuca sativa L.) $(63,64)$.

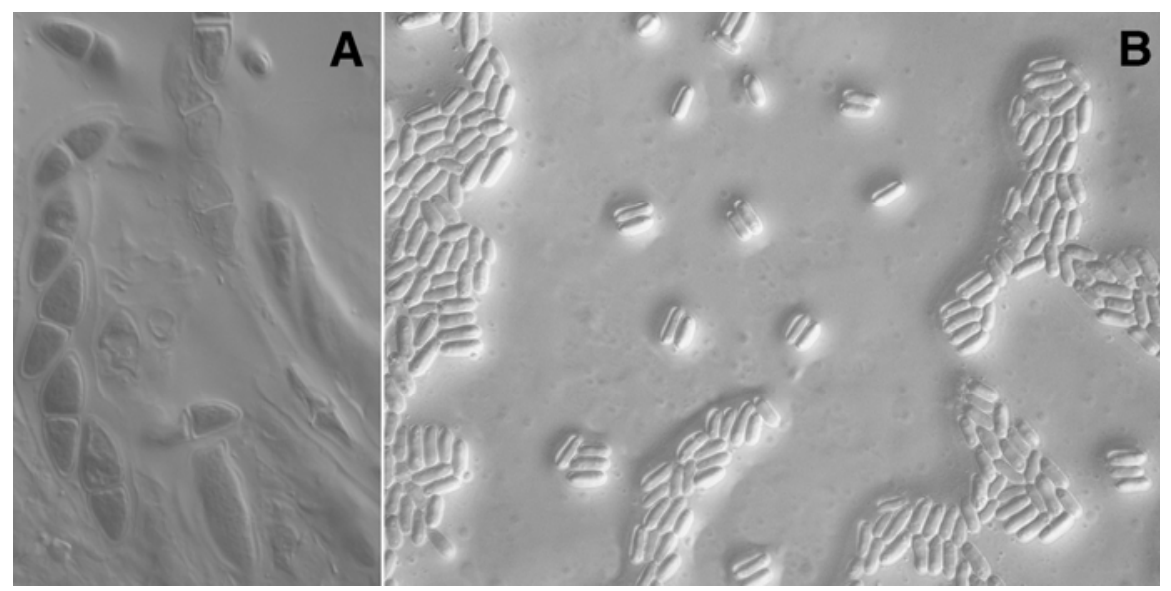

Fig. 4. A, Asci and ascospores of Didymella ligulicola var. ligulicola, the teleomorph of Phoma ligulicola var. ligulicola, from a herbarium specimen isolated from ray blightaffected chrysanthemums in Germany (DZ 62547). B, Conidia of $P$. ligulicola var. inoxydablis isolated from diseased pyrethrum tissue in Tasmania, Australia.
Epidemiology and challenges with ray blight of pyrethrum. As with many other plant diseases $(33,40,55,91,92)$, spatiotemporal characterization of ray blight epidemics of pyrethrum in Tasmania have assisted in developing hypotheses on how inoculum was first introduced into individual fields, the relative contribution of inoculum within and among fields to the epidemics, and development of appropriate sampling strategies to assess disease incidence and severity. For ray blight of pyrethrum, these analyses detected the presence of steep spatial gradients in fields approaching harvest in the first year of production (61). The foci were attributed to inoculum originating within the field (e.g., infected seedlings that developed from infested seed) and conidial dispersal by rain splash from infected plants. Despite the absence of the teleomorph of this pathogen in Tasmania, the importance of inoculum sources from outside individual fields was suggested in fields approaching the second year of harvest (61). In all fields, the increase in disease intensity in spring was rapid, and models representative of polycyclic disease growth (logistic and Gompertz) were found to best describe the changes in defoliation severity and the incidence of stems and flowers with ray blight symptoms with respect to time (61).

Spatio-temporal analyses of epidemics required routine assessment of the incidence and severity of ray blight within and among pyrethrum fields (61). This involved physical removal of the primary sampling unit, the flowering stem. However, this destructive sampling was laborious and introduced sampling bias and errors because removal of stems from the dense pyrethrum canopy caused damage to adjacent plants in the field. To minimize the sampling error, remote sensing using a multispectral radiometer $(49,50,52-54$, 83,88 ) was validated for use in pyrethrum $(65,66)$. The multispectral radiometer 
helped minimize damage associated with visual disease intensity assessments, and reduced rater bias associated with destructive sampling. Similar to other diseases $(49,52,79,88)$, reflectance within the nearinfrared range $(830 \mathrm{~nm})$ and the difference vegetative index (DVI) provided the most accurate, precise, and reproducible estimates of disease intensity (66), as well as yield components such as the dry weight of flowers and pyrethrin yield (65).

Rapid development and deployment of management strategies for ray blight in Tasmanian pyrethrum crops. The design and adoption of management strategies to minimize losses caused by ray blight was of paramount importance to the Tasmanian pyrethrum industry. Firstly, plant measurements such as stem height, the number of stems produced by each plant, and number of flowers per stem, as well as disease severity, were found to be significantly correlated to pyrethrin yield (65). Moreover, the application of fungicides in the spring to reduce disease intensity provided additional yield benefits by increasing the numbers of healthy flowers per stem in treated plots versus nontreated plots. The concept of subminimal thresholds (34) was used to model interactions between each of the measures of disease severity on the same sampling unit (60). A defoliation severity threshold of $35 \%$ was needed before stem lesion severity in- creased linearly, and a threshold of $38 \%$ before the incidence of flowers with ray blight increased linearly. The threshold for severity of stem lesions was $14 \%$ before the incidence of flowers with ray blight increased linearly. These thresholds were derived from fungicide efficacy trials in commercial fields, which also quantified the effect of ray blight on yield (60). Thus, fungicides applied prior to mid-October (early spring) were demonstrated to be the most effective short-term measure for disease management, and significantly reduced disease incidence and severity and increased pyrethrin yields by nearly $80 \%$ $(60,68,71)$.

Unfortunately, little could be learned about the management of ray blight in Tasmania from the management of ray blight in chrysanthemum and other pyrethrum production areas because of production differences in Tasmanian pyrethrum crops versus chrysanthemum production and in other regions of pyrethrum production. Additionally, fungicides previously used to manage ray blight in these other production systems are no longer available or have been superseded by chemistries in different resistance classes. In pyrethrum crops in East Africa and Papua New Guinea, fungicides are not cost-effective for disease management (94). Fungicides found to be effective for chrysanthemum ray blight include ethylene-bis-dithio- carbamates $(2,8,89)$, captan (8), benomyl, chlorothalonil, and dichloronaphthoquinone (8). For management of ray blight in pyrethrum, azoxystrobin (a strobilurin fungicide) and a range of other products belonging to the demethylation inhibitor (DMI) group (including difenoconazole) were demonstrated to be efficacious (71). In trials in 2002 and 2003, applications of azoxystrobin doubled the yield of pyrethrum flowers compared to nontreated control plots, with no measurable fungicide effect on the weight of individual flowers or flower maturity (71). These trials provided the basis for commercial recommendations consisting of several applications of these effective fungicides. The benefits of these products were linked with protection of the developing flowering stems, so the initial application was recommended when shoots of developing stems were approximately 5 to $10 \mathrm{~cm}$ above the ground (67). These recommendations were validated on a larger scale, when the effects of the fungicides on disease incidence, severity, and yield were studied in 96 commercial fields in 2003 and 2004. Nontreated areas of pyrethrum crops were maintained in commercial fields, with growers agreeing not to apply fungicides to the premarked areas within their field in spring. Results from these trials indicated that (on average) the recommended fungicide program increased

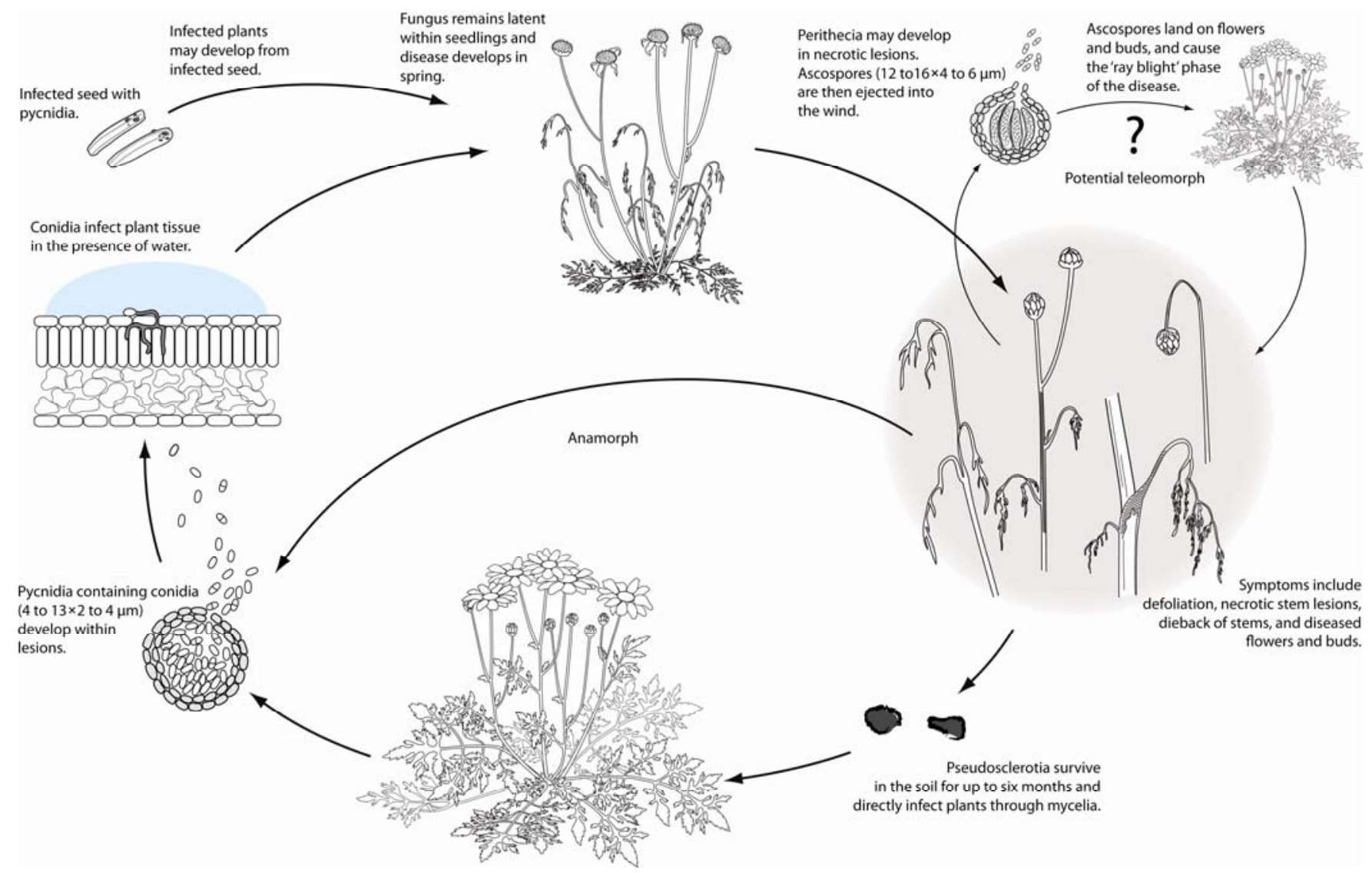

Fig. 5. Life cycle of Phoma ligulicola var. inoxydablis, cause of ray blight in Tasmanian pyrethrum fields. Contribution of a teleomorph stage is at present unknown. (Illustrated by Vickie Brewster) 
the dry weight of flowers by $72 \%$ and pyrethrin yield by $79.5 \%$ compared to nontreated plots within each field (Fig. 6; 60). Apart from gathering cost/benefit information from the application of fungicides, this study also facilitated rapid adoption of the fungicide program by the industry (90\% of pyrethrum growers in Tasmania within 2 years). Growers were able to examine the disease within the nontreated areas, identify symptoms of the disease, and visually evaluate the effects of fungicides applied to their fields during the season. Thus, growers and industry field officers involved in this study subsequently helped transfer the information and recommendations to other growers.

The rapid adoption of the management program for ray blight was successful because it addressed five of the critical elements for successful diffusion of an innovation as described by Rodgers (82): (i) the "relative advantage" of the management program was evident to growers, as it increased pyrethrin yield by almost $80 \%$; (ii) the management recommendations were compatible with current practices and relatively simple for growers to interpret; (iii) growers were able to test and observe the management program in their own crops before making decisions on whether to adopt this innovation, which reduced their perceived risks; and (iv) communication of the program with other growers accelerated the dissemination of management recommendations to the entire industry. Another critical element for this successful technology transfer was the close involvement of dedicated field staff employed by the pyrethrum industry to give agronomic advice to growers and promote these changes in management practices. The major measure of success of the fungicide program is that over $90 \%$ of the Tasmanian pyrethrum industry has continued to follow the recommendations since they were first introduced in $2002(68,71)$.

By 2004, concerns over reduced sensitivity of $P$. ligulicola var. inoxydablis strains in Tasmania to azoxystrobin and difenoconazole, and the durability of the spring fungicide program, were developing (35). According to the Fungicide Resistance Action Committee (FRAC), the strobilurin and DMI fungicides are classified as medium to high risk of resistance development, and prone to development of directional selection for resistant strains of fungal populations $(9,25,84)$. Recent studies have shown evidence of reduced sensitivity to difenoconazole, but not to azoxystrobin in Tasmanian isolates of $P$. ligulicola var. inoxydablis (35). Tebuconazole, another DMI fungicide, also is applied as part of the summer fungicide program to manage Sclerotinia and Botrytis flower blights (39). Therefore, there was a need for fungicides with different modes of action to replace difenoconazole. After 3 years of trials (68), boscalid was chosen to replace difenoconazole in commercial fungicide recommendations for management of ray blight in Tasmania in 2006. This introduced a fungicide with a different mode of action than those used in pyrethrum production $(16,38)$. The trials also demonstrated that pyraclostrobin was highly effective in reducing disease incidence and severity, and as another member of the strobilurin fungicides, it could be used instead of azoxystrobin in this fungicide program (68). An additional benefit of incorporating boscalid into the spring fungicide program has been improved management of crown rot caused by Sclerotinia $\mathrm{spp}$. (68).

To negate the reliance on fungicides to reduce the risk of ray blight in pyrethrum crops in Tasmania, other integrated management tactics have also been employed. Site selection and cultivar selection for reduced disease risk have proven beneficial in reducing the risk of epidemics. Pethybridge and Hay (62) have demonstrated that field aspect and elevation had a significant effect on ray blight in spring, and hence, the need to apply fungicides in the spring. In Tasmania, pyrethrum fields on north-facing slopes have significantly less ray blight than fields on south-facing slopes. Moreover, pyrethrum fields grown on the tops of hills had lower levels of disease compared to those in valleys. These observations were most likely the result of the effect of environmental conditions that affect disease risk (e.g., duration of leaf wetness), as supported by significant positive correlations between disease severity and the number of consecutive days with rain during spring (67). Furthermore, of the four primary pyrethrum culti- vars used in Tasmania, two are relatively more susceptible to ray blight than the others (S. J. Pethybridge, unpublished data). Thus, the combination of site risk factors (aspect and elevation) and cultivar selection should be weighted against the benefits of applying an entire spring fungicide program versus fewer spring applications. If field sites are selected that have higher site risks (aspect and elevation), the risk of a ray blight epidemic may be somewhat lowered by planting a relatively resistant cultivar and/or by using an appropriate fungicide program. Interestingly, for ray blight of chrysanthemum and in pyrethrum production elsewhere, management of ray blight focuses primarily on the use of resistant cultivars $(2,89)$. Agronomic practices such as avoiding overhead irrigation, minimizing the use of fertilizers (8), roguing and burning diseased plants $(8,89)$, reducing plant density to reduce the hours that plants remain wet $(7,8)$, and planting material certified to be free of $P$. ligulicola (8) are standard recommendations for ray blight management in chrysanthemum.

\section{Botrytis Flower Blight and Sclerotinia Diseases}

Botrytis flower blight and diseases caused by Sclerotinia spp. cause significant annual losses of flowers and plants in Tasmanian pyrethrum fields (39). Two species of Sclerotinia found in Tasmanian fields, S. sclerotiorum and $S$. minor, are capable of causing crown rot through myceliogenic germination (Fig. 7), but crown rot is most often attributed to the latter species in Tasmania (39). The first symptom of crown rot is wilting, followed

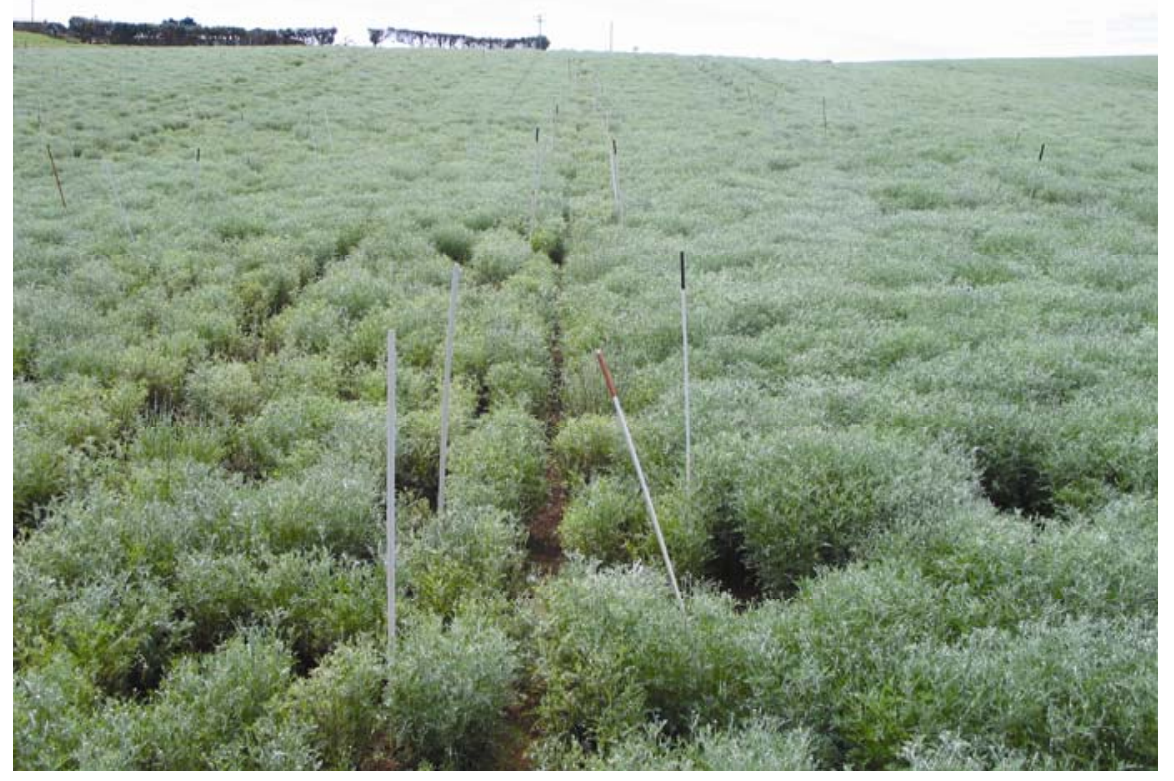

Fig. 6. Lower severity of ray blight of pyrethrum caused by Phoma ligulicola var. inoxydablis, and enhanced plant growth from the application of azoxystrobin (right) compared to a nontreated plot (left). 
closely by death of the entire plant. Infected stems appear bleached and often are associated with the presence of cottony mycelium and sclerotia typical of either species (Fig. 8). Crown rot caused by $S$. minor also causes death of pyrethrum plants in East Africa (47). Despite extensive studies of these pathogens on other crops, little is known regarding the epidemiology of these diseases in pyrethrum. For example, epidemics of white mold in other crops are usually initiated by ascospores released from apothecia produced on sclerotia (1). Apothecia production occurs after sclerotia are exposed to cool, moist conditions (1). In the absence of detailed epidemiological information, we assume that following carpogenic germination of apothecia from sclerotia of S. sclerotiorum, ascospore deposition occurs on disk florets, and that in the presence of moisture, ascospores germinate and directly infect flowers (Fig. 7; 15). However, predictive modeling has suggested that Tasmanian conditions are also suitable for carpogenic germination of $S$. minor (26). Thus, $S$. minor may play a role in Sclerotinia flower blight in Tasmania.

Symptoms of Sclerotinia flower blight in pyrethrum involve necrosis of the ray and disk florets which remain intact, followed by a bleached appearance extending
1 to $2 \mathrm{~cm}$ into the stem from the peduncle (Fig. 9A). Sclerotia may be visible within diseased flowers, which drop to the ground during harvest and thereby contribute to an increase in soilborne inoculum. Symptoms of Botrytis flower blight in pyrethrum first appear as necrotic lesions on the disk florets (similar to Sclerotinia flower blight). However, disk florets generally fuse together (Fig. 9B). Conidia are produced profusely on flowers prior to harvest. Conidia may continue to be produced while the flowers are in windrows (especially if the windrows remain wet before harvest).

Because Botrytis flower blight occurs at the same growth stage (flowering) as Sclerotinia flower blight, management programs in pyrethrum focus on both diseases (39). However, management of these diseases remains difficult and less than satisfactory. The current recommendations include four to five fungicide applications at 10- to 14-day intervals throughout the susceptible (flowering) period. Only two fungicides are used in Tasmania for these two diseases, carbendazim and tebuconazole, which are applied alternately. Currently, up to 20 applications of each fungicide may be made over the commercial life of a pyrethrum crop in Tasmania. Such intensive use of these products is a concern for the development of resistance to these fungicides. Preliminary evidence of reduced sensitivity of $B$. cinerea to carbendazim has been found (S. J. Pethybridge and $\mathrm{H}$. Cole, unpublished data). Outbreaks of flower diseases usually occur in conjunction with prolonged leaf wetness associated with periods of increased frequency and duration of summer rainfall and overhead irrigation, and indicate that current disease management approaches are inadequate. Practical alternatives to fungicides are unlikely in the short-term. Sclerotinia and some Botrytis species are plurivorous necrotrophic pathogens (87), and are able to survive in the soil as sclerotia, making management by rotation alone difficult. Potential rotation crops for pyrethrum in Tasmania include bean, carrot, lettuce, and potato, which also are susceptible to $S$. sclerotiorum (15). Further complicating the management of Sclerotinia spp. are strong associations of disease pressure with cultural practices that optimize yield potentials, such as high plant population densities (11), narrow row spacing (14), and lush plant growth from using high amounts of water (especially overhead irrigation) and fertilizers (45,87). These inputs are recommended for optimizing yields in pyrethrum production in Tasmania, and are difficult to manipulate without potentially reducing yields.

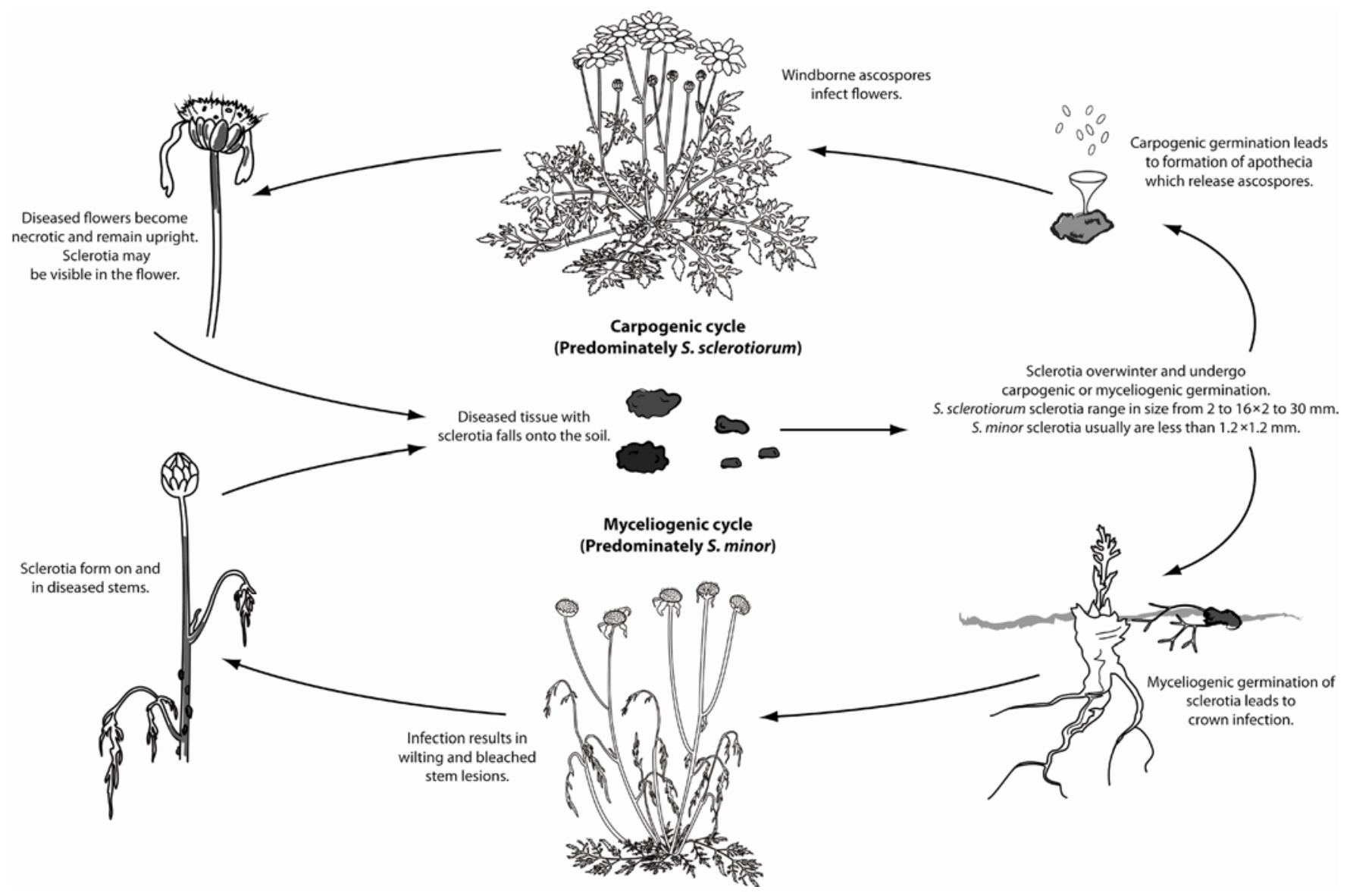

Fig. 7. Life cycle of Sclerotinia sclerotiorum, cause of Sclerotinia flower blight of pyrethrum and crown rot, contrasted to that of S. minor, the predominant cause of crown rot in Tasmanian pyrethrum fields. (IIlustrated by Vickie Brewster) 


\section{Diseases Caused by Nematodes}

Injury to pyrethrum crops caused by nematodes is a serious problem in pyrethrum production areas of Tasmania and East Africa (3,32,57). In Tasmania, lesion nematodes (Pratylenchus spp.) are the most prevalent of the plant-parasitic nematodes, occurring in all fields surveyed (32). Low population densities with less than one nematode $/ \mathrm{cm}^{3}$ soil, and some fields with population densities of $>3$ Pratylenchus individuals $/ \mathrm{cm}^{3}$ soil have been found in Tasmanian pyrethrum fields prior to planting (32). The most common lesion nematodes found in Tasmanian pyrethrum fields were $P$. crenatus and $P$. penetrans, whereas $P$. neglectus and $P$. thornei occur sporadically (32). Tasmanian pyrethrum cultivars may be a host of each species, except $P$. thornei. Moreover, $P$. penetrans can multiply readily on pyrethrum (Fig. 10). In pot trials, the ratio of final to initial population densities ranged from 2.5 to 10.3 for the four cultivars most commonly grown in Tasmania. P. penetrans significantly reduced the dry weight of roots and foliage in pot trials, as well as in field trials, in which nematode population densi- ties were manipulated with the nematicide fenamiphos. Three months after sowing, pyrethrum plots treated with fenamiphos or methyl bromide had 12 and 83 times fewer lesion nematodes/g dry root weight, respectively, compared with nontreated plots. Moreover, treated plots had 2.6 and 2.9 times higher foliar dry weight, respectively, than nontreated plots, with no effects on plant density. At first harvest, yields of pyrethrins/ha from nematicidetreated plots were not significantly different from yields of nontreated plots. However, the average yield of plots treated with methyl bromide was 1.4 times higher than that of nontreated plots. At second harvest, the average yield of pyrethrins from plots treated with nematicide or methyl bromide was 1.4 to 1.5 times higher than that of nontreated plots (32). Despite demonstrated yield losses caused by lesion nematode (Fig. 11), potential management strategies prior to planting (e.g., fumigation with chemicals, use of biofumigant plants, and crop rotation), or after planting (e.g., regular applications of nematicides) are considered too costly and efficacy is limited by predominantly heavy clay soils.
Consequently, these nematode management practices are currently not utilized in pyrethrum crops in Tasmania.

In Kenya, both root-knot nematode (Meloidogyne hapla) and lesion nematode (Pratylenchus penetrans) have been reported to cause significant injury to pyrethrum in nurseries and commercial fields $(3,57)$. Injury from root-knot nematode is considered to be higher in short rotations between pyrethrum crops in Kenya and in sandier soils in which populations can increase quickly. Symptoms of root-knot nematode injury include large galls on roots, hairy and stubby roots, and severely restricted root growth, which can lead to plant death in susceptible cultivars. Injury caused by root-knot nematodes (and likely lesion nematodes) can facilitate infection by Fusarium spp. and cause a lethal wilt disease $(37,48)$. Regular applications of fenamiphos at a site infested with $M$. hapla and $P$. penetrans in Kenya increased the dry weight of flowers 1.3 to 1.8 times that of nontreated plots and significantly decreased the population densities of plantparasitic nematodes and galling of roots from root-knot nematode compared to

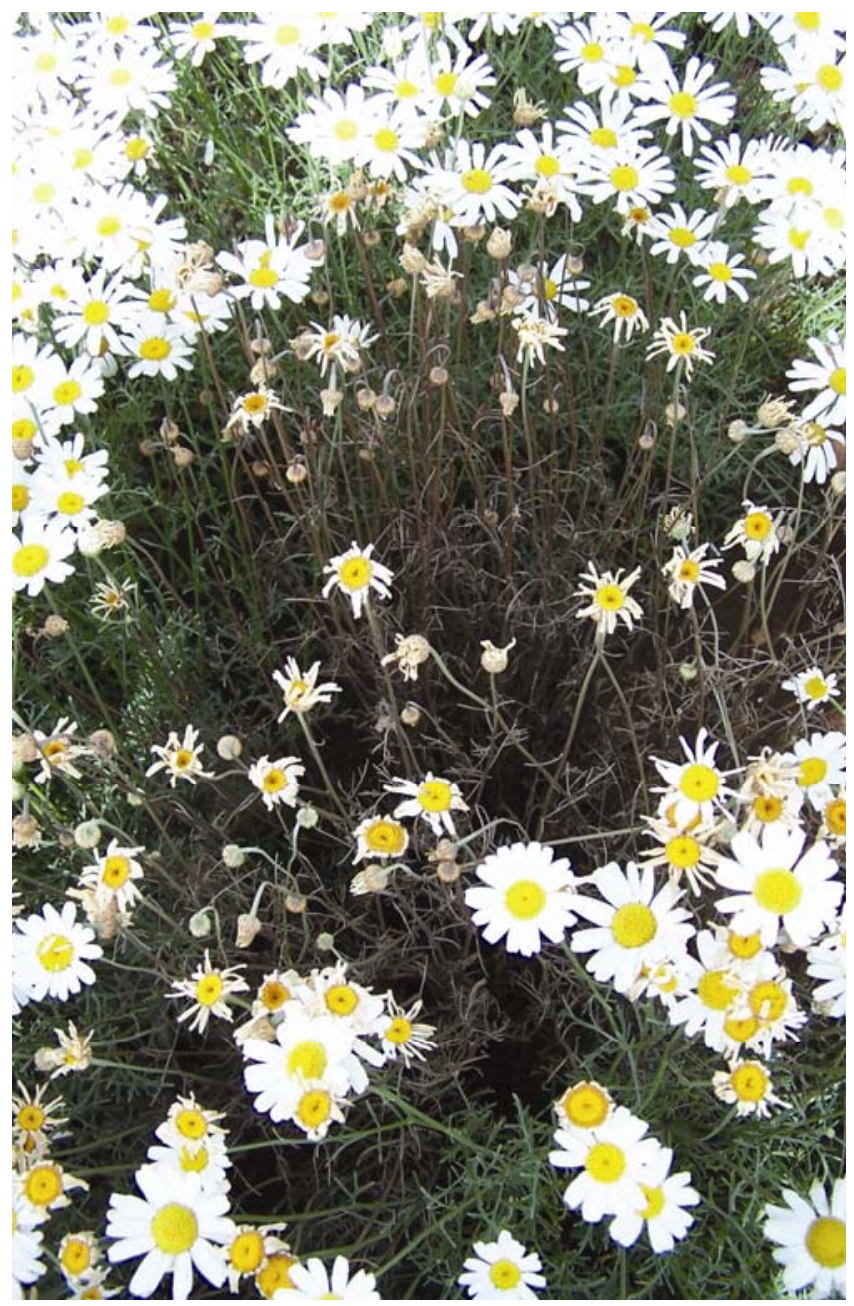

Fig. 8. Sclerotinia crown rot of pyrethrum caused by Sclerotinia minor. Bleached lesions and small sclerotia can be found on stems and peduncles near the soil surface.

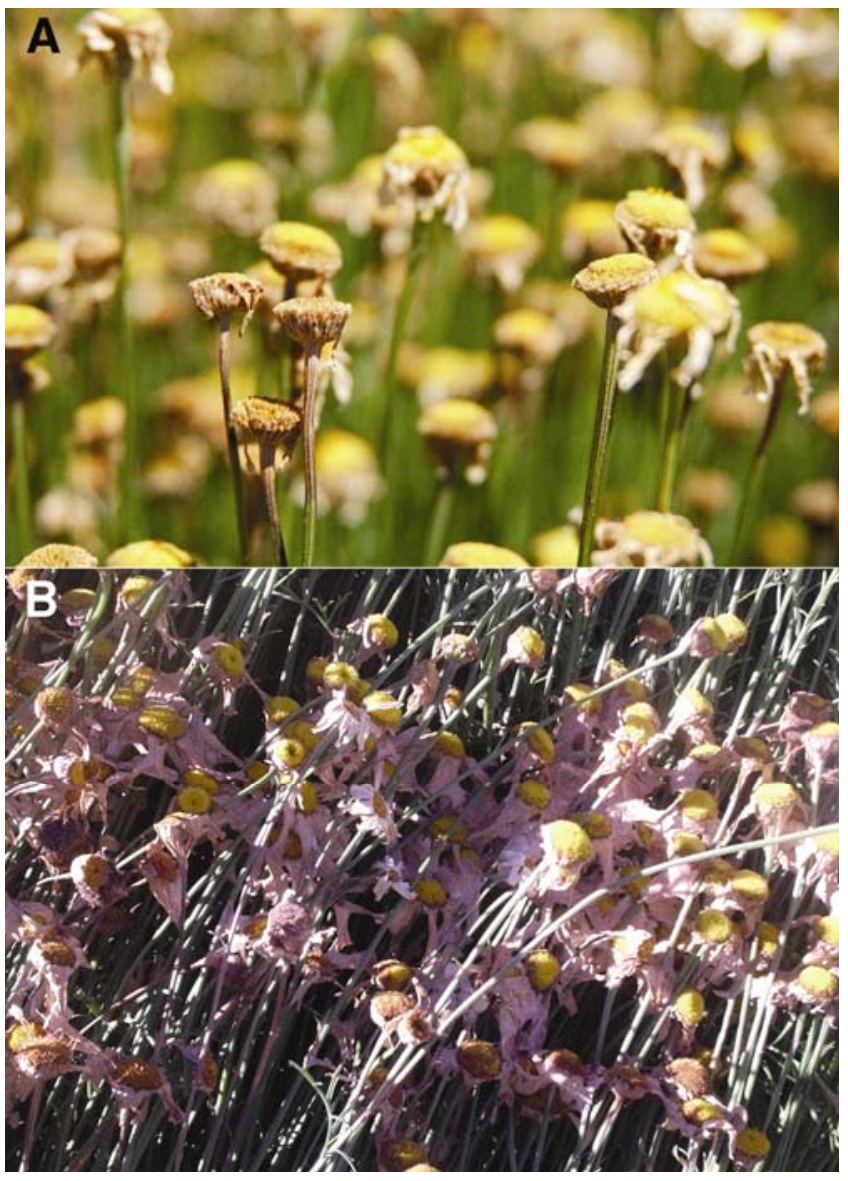

Fig. 9. A, Pyrethrum flowers affected by Sclerotinia flower blight, caused by Sclerotinia sclerotiorum, become necrotic and the lesions extend into the peduncle and stem. Affected flowers remain upright. B, Symptoms of Botrytis flower blight, caused by Botrytis cinerea, include necrotic flowers and disk florets that become stuck together. Sporulation of $B$. cinerea may be present, especially under moist conditions. 
nontreated plots in trials conducted over a 4-year period (4). Effective management of $M$. hapla has also been achieved by rotating pyrethrum with a cereal crop (such as maize) for 1 year, followed by the use of nematode-tolerant pyrethrum cultivars, which are able to endure infestations by nematodes without increasing damage or yield loss $(3,4)$. Root-knot nematode has been found in $20 \%$ of pyrethrum fields in Tasmania, and in $15 \%$ of these fields, population densities were $>0.25$ Meloidogyne individuals $/ \mathrm{cm}^{3}$ soil (51). Species of root-knot nematode known to occur in Tasmania are $M$. arenaria, $M$. fallax, $M$. incognita, and M. hapla (51). Despite rootknot nematodes being a sporadic problem in vegetable crops grown in the same region (31), typical signs and symptoms of root-knot nematode injury, such as the production of galls on roots and reduced plant vigor, have never been found. This suggests that commercially grown cultivars in Tasmania are resistant to root-knot nematode.

\section{Other Diseases of Pyrethrum in Tasmania}

Tan spot (caused by Microsphaeropsis tanaceti sp. nov.), winter blight (caused by Alternaria tenuissima), and pink spot (caused by Stemphylium botryosum) are commonly found in Tasmanian pyrethrum fields $(67,70,72,73)$ (Fig. 12). Symptomless infections with TSWV also are common. Symptoms of tan spot include tancolored spots that coalesce around the margins of leaves $(72,73)$. The prevalence and incidence of tan spot has substantially increased since its first description in Tasmania in 2001 (67). The occurrence of tan spot varies temporally according to the season and, along with ray blight, contributes to defoliation in spring $(72,73)$. Therefore, the spring fungicide program used by pyrethrum growers in Tasmania targets the management of both diseases to minimize yield losses $(68,71)$.

Winter blight and pink spot are commonly found on the semi-dormant rosette stage of pyrethrum plants during winter $(67,70)$. Both diseases are not considered to be yield-limiting, and therefore, management tactics have not been necessary. The symptoms of these two diseases differ markedly following inoculation, but under field conditions the diseases can be difficult to distinguish because of secondary fungi that colonize the lesions, as well as frost and herbicide injury which cause similar symptoms to those caused by winter blight. Typical symptoms are small necrotic spots (generally $<0.5 \mathrm{~cm}$ in diameter) on leaves which coalesce to encompass large areas. Necrotic lesions associated with Alternaria spp. also have been reported on pyrethrum in East Africa $(46,48,81,86)$, but no information is available on the species identification. Alternaria alternata causes disease in chrysan- themum flowers (23), but did not elicit symptoms when inoculated onto pyrethrum foliage (70).

Pink spot of pyrethrum is characterized by lesions on leaves that exhibit necrotic halos surrounded by pink/brown margins. The teleomorph, Pleospora herbarum, is commonly found on pyrethrum stems after harvest (70). Diseases caused by $S$. floridanum have been reported in chrysanthemum (90) and China aster (5). All pyrethrum cultivars currently grown in Tasmania appear to have similar levels of susceptibility to tan spot, winter blight, and pink spot $(70,72,73)$.

TSWV is the only virus reported to infect pyrethrum, and infections have been found to be symptomless following inoculation trials (96) and from observations of natural infections in Tasmanian pyrethrum fields (detected by enzyme-linked immunosorbent assay and confirmed by reverse transcription-polymerase chain reaction) (76). TSWV infection of chrysanthemum also may be symptomless (41), although ring spots, chlorosis, and stunting have been reported (97). TSWV was found to be prevalent, occurring in $85 \%$ of pyrethrum crops approaching the fourth harvest, with the incidence of infection within each field as high as $11.3 \%$ (76). The incidence of TSWV in pyrethrum fields in the central coast region of Tasmania was significantly higher than in others areas of Tasmania. This district is more intensively cropped than the others surveyed, with a variety of vegetables, alkaloid poppy, and cut flowers comprising the predominant crops. More-

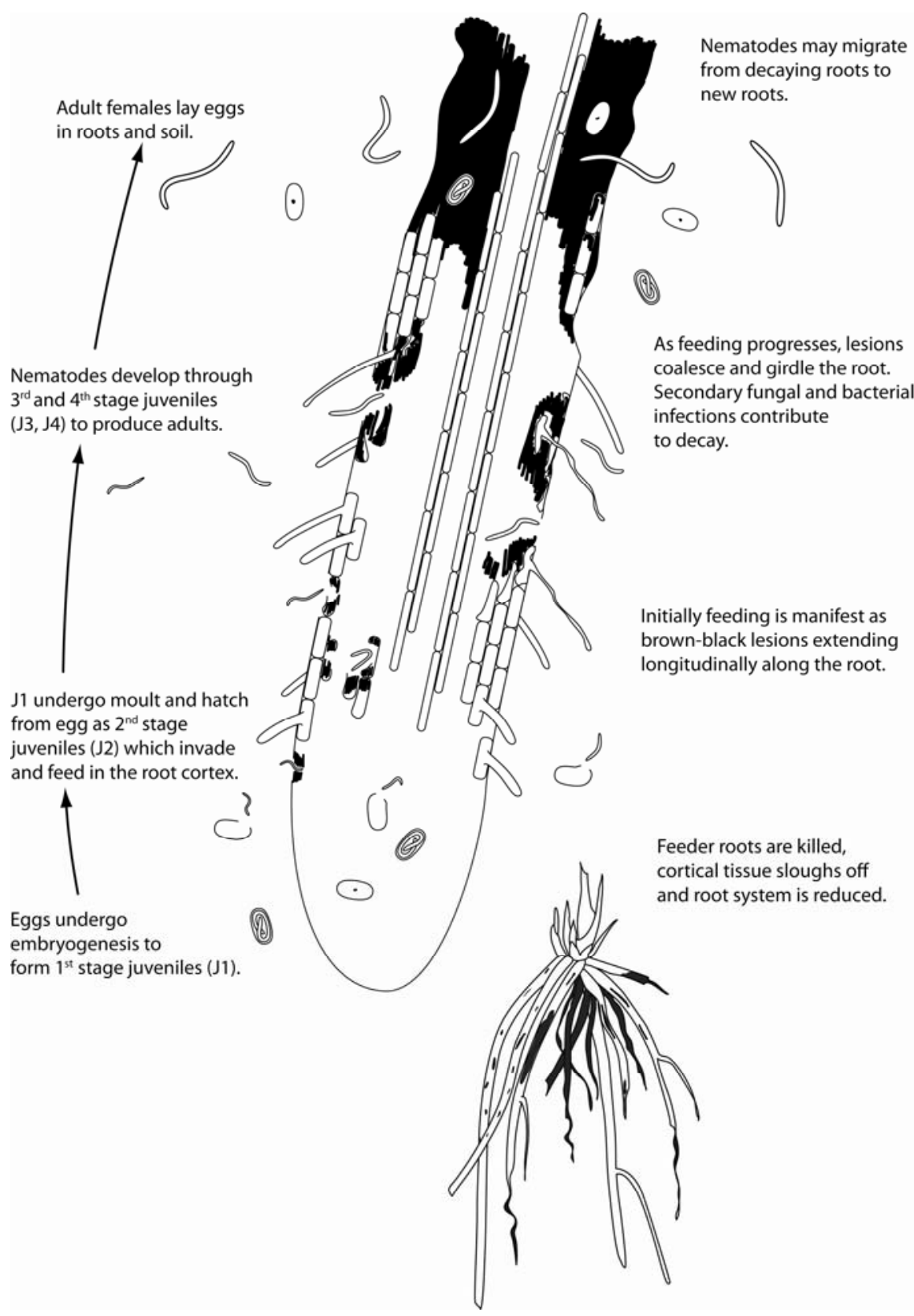

Fig. 10. Life cycle of the lesion nematode, Pratylenchus spp., which can cause root damage to pyrethrum. (Illustrated by Vickie Brewster) 
over, fallow fields and headlands containing potential weed hosts of TSWV are common in this area. Furthermore, onion thrips (Thrips tabaci), the predominant vector of TSWV in Tasmania (95), is commonly found on pyrethrum during flowering (T. Groom, unpublished data).

\section{Future of Pyrethrum Disease Management in Tasmania}

In Tasmania, disease research in pyrethrum has focused on reducing losses and optimizing costs versus benefits of applying fungicides for management of the prevalent fungal diseases: ray blight, Sclerotinia crown rot, Sclerotinia flower blight, and Botrytis flower blight. However, management programs for these diseases that include alternatives to fungicides may reduce variable costs (e.g., chemicals and their application costs) to growers associated with disease management, and can lead to a greater return on investments. For long-term profitability, the identification and deployment of cultivars with greater levels of resistance or tolerance to these diseases than the cultivars currently grown is one tactic the Tasmanian pyrethrum industry can learn from the low input pyrethrum production systems in East Africa and Papua New Guinea. For ray blight, there are minor differences in the susceptibility of cultivars currently grown. However, in Tasmania, currently the use of a cultivar with reduced susceptibility alone appears effective only when disease pressure is low, but it does allow for a reduction in the number of fungicide applications in spring (generally one fungicide application can be omitted by planting a more resistant cultivar). However, even with more resistant cultivars, growers often remain risk averse and continue to utilize a complete fungicide program of three applications for ray blight, regardless of the disease pressure within their fields and/or weather forecasts. No sources of immunity have been identified for ray blight within the commercially adopted cultivars in Tasmania.

Changes in pyrethrum production practices also may be used to reduce the severity of these diseases in Tasmania. In the low-input systems of East Africa and Papua New Guinea, seedlings are generally planted at wide spacing. Thus, humidity and the periods of leaf wetness are lower, resulting in a reduction in the rate of disease development compared with conditions of higher humidity and extended periods of leaf wetness that increase disease risk. In the more input-intensive systems of Tasmania, plant density is higher and canopy closure occurs by approximately mid-October through harvest (December). Moreover, overhead irrigation commonly used in Tasmania during flowering provides favorable conditions for fungal diseases in this environment $(11,42-44,78,87)$. However, a reduction in plant density does not come without a cost. In preliminary studies in which plant density was reduced by 50 to $75 \%$, ray blight severity was reduced by $18 \%$ without a reduction in pyrethrin yield (S. J. Pethybridge, unpublished data). However, there was an increase in weed density at the lowest plant density of pyrethrum, which required additional herbicide applications and increased variable production costs. One shift in agronomic practices in Tasmania that is currently under investigation for management of ray blight is the deployment of cultivar mixtures $(30,98)$. In other crops, cultivar mixtures have effectively reduced disease severity by increasing the distance between resistant and susceptible plants (reducing the incidence of alloinfection), thereby reducing the rate of temporal and spatial disease increase. Resistant plants also may provide a physical and physiological barrier against spore dispersal of some fungal pathogens (22). If effective, cultivar mixtures may be adopted readily by the Tasmanian pyrethrum industry as yield is measured based on the quantity of pyrethrins, not pyrethrin quality.

For effective disease management programs to be implemented in pyrethrum crops in Tasmania, further knowledge is

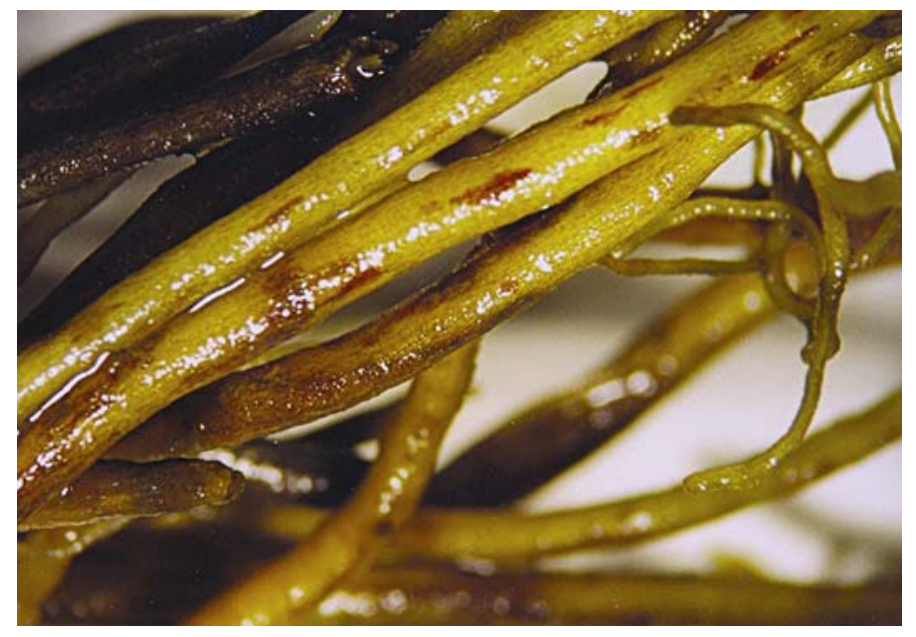

Fig. 11. Injuries caused by lesion nematode, Pratylenchus spp., appear on the pyrethrum roots as small, brown lesions, which initiate rotting and a reduction in root mass.

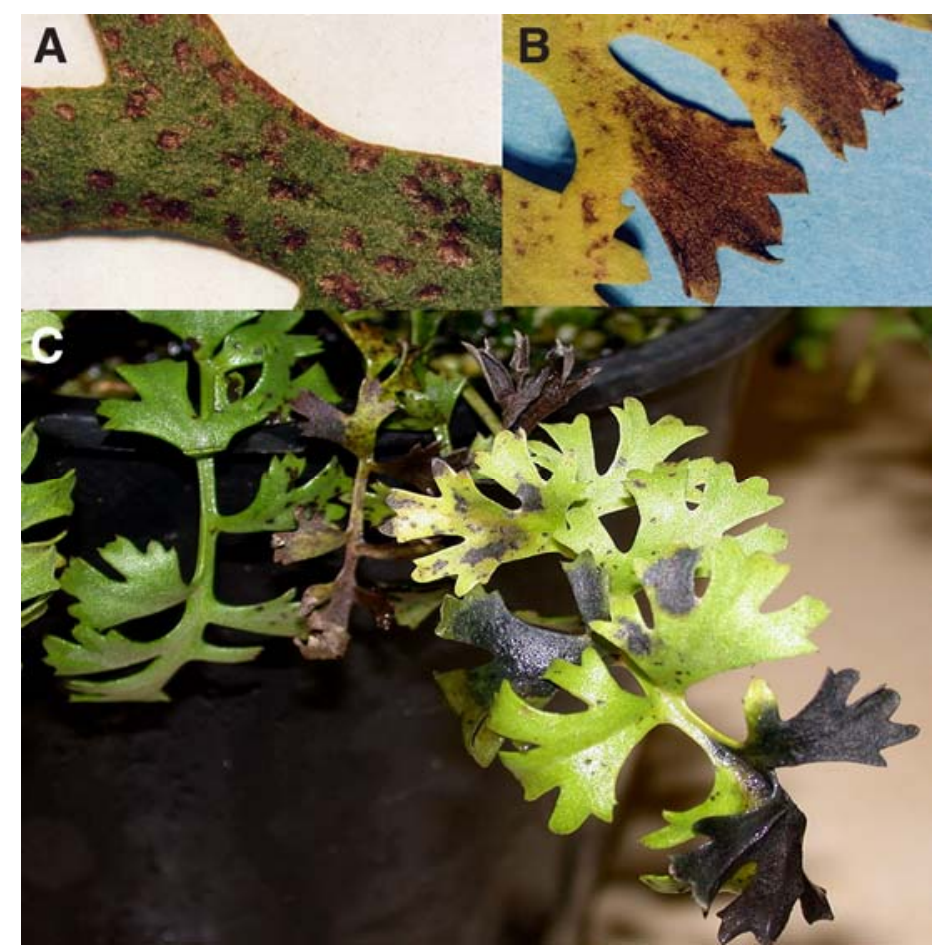

Fig. 12. A, Symptoms of pink spot, caused by Stemphylium botryosum, are necrotic halos surrounded by a pink/brown margin on pyrethrum leaves. B, Symptoms of winter blight, caused by Alternaria tenuissima, are small, necrotic spots that coalesce to form necrotic patches on pyrethrum leaves. C, Symptoms of tan spot, caused by Microsphaeropsis tanaceti sp. nov., are also found on pyrethrum leaves and consist of small, tan-colored spots. 
required of the etiology and epidemiology of many of the pathogens that affect this host species. For example, to fully assess the impact of TSWV on pyrethrum production, detailed information on production losses can be generated by modeling yield losses associated with TSWV. For ray blight, the presence or absence of a teleomorph and determination of whether P. ligulicola var. inoxydablis is homothallic or heterothallic is critical for assessing the potential for long-distance dispersal of wind-blown inoculum of this pathogen. Validation of the environmental conditions that favor ray blight epidemics also is needed. The relationship among environmental conditions (42-44), host growth stages, and disease severity has been well described for ray blight of chrysanthemum caused by $P$. ligulicola var. ligulicola, and formed the basis of one of the first plant disease simulators, MYCOS (42). Such information for P. ligulicola var. inoxydablis and pyrethrum could be used to schedule fungicide applications more effectively than using a calendar-based fungicide program.

A greater understanding is required of the environmental conditions of both Sclerotinia flower blight and Botrytis flower blight of pyrethrum that affect spore release and dispersal, and how to best integrate ontogenic (developmental) resistance into disease management programs. The management program currently utilized by growers for these two diseases is primarily a prophylactic approach throughout the flowering period. Early detection or model forecasts of ascospore release by S. sclerotiorum could be used to assess when to initiate management measures, such as the timely application of fungicides. Understanding the flowering stages that are highly susceptible to both pathogens may further improve effective timing of fungicide applications. For several other crops, detection of ascospores of S. sclerotiorum by polymerase chain reaction has been accomplished, but this detection tool has not yet been implemented into disease management programs (28). This technology requires further testing and validation for implementation on pyrethrum farms in Tasmania.

Sustainable management of pyrethrum diseases in Tasmania at present requires the judicious use of chemical inputs as made possible by a more complete understanding of the etiology, epidemiological risk factors, and economic thresholds of specific diseases that limit yields in Tasmania. The challenge for long-term management of pyrethrum diseases in Tasmania will be to develop more ecologically based disease management programs that enhance productivity and profit margins. Current research efforts are addressing these challenges.

\section{Acknowledgments}

We extend our thanks to the financial supporters of our research and extension programs including
Botanical Resources Australia Pty. Ltd., Tasmanian pyrethrum growers, the Australian Research Council (programs LP0211065 and LP0560562), and Horticulture Australia Ltd. We also thank our collaborators: Graham Stirling, Biological Crop Protection, Queensland, Australia; and Suzanne J. Jones, Tom O'Malley, and Craig Palmer, Tasmanian Institute of Agricultural Research, University of Tasmania. Thanks also to those who have provided excellent technical support within our respective programs.

\section{Literature Cited}

1. Abawi, G. S., and Grogan, R. G. 1979. Epidemiology of diseases caused by Sclerotinia species. Phytopathology 69:899-904.

2. Anonymous. 1956. Ray blight of chrysanthemums. Agric. Gaz. 309-310.

3. Anyango, J. J. 1988. The effect of root knot and lesion nematodes on pyrethrum seedlings in Kenya. Acta Hortic. 218:355-358.

4. Anyango, J. J., Ngugi, C. W., and Ikahu, J. M. K. 1991. The effect of granular nematicides on the control of root-knot and lesion nematodes in pyrethrum (Chrysanthemum cinerariaefolium vis.). Pyrethrum Post 18:100-103.

5. Baker, K. F., and Davis, L. H. 1950. Stemphylium leaf spot of China aster. Mycologia 42:477-486.

6. Baker, K. F., and Davis, L. H. 1959. Ascochyta disease of chrysanthemum appears in California. Calif. State Florists Assoc. Mag. 8:A-B.

7. Baker, K. F., Dimock, A. W., and Davis, L. H. 1949. Life history and control of the Ascochyta ray blight of chrysanthemum. Phytopathology 39:789-805.

8. Baker, K. F., Dimock, A. W., and Davis, L. H. 1961. Cause and prevention of the rapid spread of the Ascochyta disease of chrysanthemum. Phytopathology 51:96-101.

9. Bartlett, D. W., Clough, J. M., Godwin, J. R., Hall, A. A., Hamer, M., and Parr-Dobrzanski, B. 2002. The strobilurin fungicides. Pest Management Sci. 58:649-662.

10. Bhat, B. K., and Menary, R. C. 1984. Pyrethrum production in Australia: Its past and present potential. J. Aust. Inst. Agric. Sci. 189192.

11. Blad, B. J., Steadman, J. R., and Weiss, A. 1978. Canopy structure and irrigation influence white mold disease and microclimate of dry edible beans. Phytopathology 68:14311437.

12. Blakeman, J. P., and Hornby, D. 1966. The persistence of Colletotrichum coccoides and Mycosphaerella ligulicola in soil, with special reference to sclerotia and conidia. Trans. Br. Mycol. Soc. 49:227-240.

13. Boerema, G. H., De Gruyter, J., Noordeloos, M. E., and Hamers, M. E. C. 2004. Phoma Identification Manual. Differentiation of Specific and Intra-Specific Taxa in Culture. CABI Publishing, Surrey, UK.

14. Boland, G. J., and Hall, R. 1987. Epidemiology of white mold of white bean in Ontario. Can J. Plant Pathol. 16:93-108.

15. Boland, G. J., and Hall, R. 1988. Epidemiology of Sclerotinia stem rot of soybean in Ontario. Phytopathology 78:1241-1245.

16. Broomfield, P. L. E., and Hargreaves, J. A. 1992. A single amino-acid change in the ironsulphur protein subunit of succinate dehydrogenase confers resistance to carboxin in Ustilago maydis. Curr. Genet. 22:117-121.

17. Brown, P. H. 1990. Morphological and physiological aspects of flower initiation and development in Tanacetum cinerariaefolium L. Ph.D. thesis. University of Tasmania, Hobart, Tasmania, Australia.

18. Brown, P. H., and Menary, R. C. 1994. Flowering in pyrethrum (Tanacetum cinerariaefolium L.): I. Environmental requirements. J. Hortic. Sci. 69:877-884.
19. Casida, J. E. 1990. Pesticides and Alternatives: Innovative Chemical and Biological Approaches to Pest Control. Elsevier Science Publishers, New York.

20. Chesters, C. G. C., and Blakeman, J. P. 1966. The survival on chrysanthemum roots of epiphytic mycelium of Mycosphaerella ligulicola. Ann. Appl. Biol. 58:291-298.

21. Chesters, C. G. C., and Blakeman, J. P. 1967. Host range and variation in virulence of $M y$ cosphaerella ligulicola. Ann. Appl. Biol. 60:385-390.

22. Chin, K. M., and Wolfe, M. S. 1984. The spread of Erysiphe graminis f. sp. hordei in mixtures of barley varieties. Plant Pathol. 33:89-100.

23. Cox, R. S. 1969. A flower blight of chrysanthemum in South Florida. Plant Dis. Rep. 53:257259.

24. David, J. C. 2004. Ramularia bellunensis. IMI Descriptions of Fungi and Bacteria. Number 161: Sheet 1607, CABI Bioscience, Surrey, UK.

25. Del Sorbo, G., Schoonbeek, H., and DeWaard, M. A. 2000. Fungal transporters involved in efflux of natural toxic compounds and fungicides. Fungal Genet. Biol. 30:1-15.

26. Ekins, M. G., Aitkin, E. A. B., and Goulter, K. C. 2002. Carpogenic germination of Scle rotinia minor and potential distribution in Australia. Aust. Plant Pathol. 31:259-265.

27. Elliott, M. 1995. Chemicals in insect control. Pages 3-31 in: Pyrethrum Flowers: Chemistry, Toxicology and Uses. J. E. Casida and G. B. Quistad, eds. Oxford University Press, New York.

28. Freeman, J., Ward, E., Calderon, C., and McCartney, A. 2002. A polymerase chain reaction (PCR) assay for the detection of inoculum of Sclerotinia sclerotiorum. Eur. J. Plant Pathol. 108:877-886.

29. Fulton, D. 1998. Pyrethrum: Agronomic and seed quality studies. Ph.D. thesis. University of Tasmania, Hobart, Tasmania, Australia.

30. Garrett, K. A., and Mundt, C. C. 1999. Epidemiology in mixed host populations. Phytopathology 89:984-990.

31. Hay, F. S., and Pethybridge, S. J. 2005. Nematodes associated with carrot production in Tasmania, Australia, and the effect of Pratylenchus crenatus on yield and quality of Kurodatype carrot. Plant Dis. 89:1175-1180.

32. Hay, F. S., Stirling, G. R., and Chung, B. 2001. Plant-parasitic nematodes associated with pyrethrum in Tasmania. Page 208 in: Proc. 13th Bienn. Aust. Plant Pathol. Soc. Conf., Cairns, Queensland, Australia.

33. Hughes, G., and Madden, L. V. 1994. Aggregation and incidence of disease: Some implications for sampling. Aspects Appl. Biol. 37:2531.

34. Johnson, K. B. 1987. Defoliation, disease, and growth - A reply. Phytopathology 77:14951497.

35. Jones, S. J., Pethybridge, S. J., Hay, F. S., Groom, T., and Wilson, C. R. 2007. Baseline sensitivity of Australia Phoma ligulicola isolates from pyrethrum to azoxystrobin and difenoconazole. J. Phytopathol. 155:377-380.

36. Katsuda, Y. 1999. Development of and future prospects for pyrethroid chemistry. Pest. Sci. 55:775-782.

37. Kimani, E. W., Waudo, S. W., Mutitu, E. W. Obukosia, S., Kimani, P. M., Ikahu, J. M. K., and Waithaka, K. 2000. Relationship between Meloidogyne hapla and Fusarium spp., in development of wilt disease. Pyrethrum Post 20:143-150.

38. Kuhn, P. J. 1984. Mode of action of carboximides. Sympos. Ser. Br. Mycol. Soc. 9:155183.

39. Macdonald, W. L. 1995. Pyrethrum flowers Production in Australia. Pages 55-66 in: Pyrethrum Flowers: Chemistry, Toxicology and 
Uses. J. E. Casida and G. B. Quistad, eds. Oxford University Press, New York.

40. Madden, L. V., and Hughes, G. 1995. Plant disease incidence: Distributions, heterogeneity, and temporal analysis. Annu. Rev. Phytopathol. 33:529-564.

41. Matteoni, J. A., and Allen, W. R. 1989. Symptomatology of tomato spotted wilt virus infection in florist's chrysanthemum. Can. J. Plant Pathol. 11:373-380.

42. McCoy, R. E. 1971. Epidemiology of chrysanthemum ascochyta blight. Cornell University, Ithaca, NY.

43. McCoy, R. E., and Dimock, A. W. 1973. Environmental factors regulating ascospore discharge by Mycosphaerella ligulicola. Phytopathology 63:586-589.

44. McCoy, R. E., Horst, R. K., and Dimock, A. W. 1972. Environmental factors regulating sexual and asexual reproduction by Mycosphaerella ligulicola. Phytopathology 62:1188-1195.

45. Mila, A. L., Carriquiry, A. L., Zhao, J., and Yang, X. B. 2003. Impact of management practices on prevalence of soybean Sclerotinia stem rot in the north-central United States and on farmers' decisions under uncertainty. Plant Dis. $87: 1048-1058$

46. Natrass, R. M. 1947. A disease of pyrethrum in Kenya. Nature 160:120-121.

47. Natrass, R. M. 1950. Pyrethrum wilt in Kenya caused by Sclerotinia minor. East Afr. Agric. J. 16:53.

48. Natrass, R. M. 1961. Host lists of Kenya fungi and bacteria. Mycological Papers No. 181. Commonwealth Mycological Institute, Kew, UK.

49. Nilsson, H. E. 1995. Remote sensing and image analysis in plant pathology. Annu. Rev. Phytopathol. 15:489-527.

50. Nilsson, H. E., and Johnsson, L. 1996. Handheld radiometry of barley infected by barley stripe in a field experiment. J. Plant Dis. Prot. 103:517-526.

51. Nobbs, J. 2003. Plant parasitic nematodes of Australian vegetables and related species. Horticulture Australia Ltd. Project no. VG98102, Sydney, Australia.

52. Nutter, F. W., Jr. 1989. Detection and measurement of plant disease gradients in peanut with a multispectral radiometer. Phytopathology 79:958-963.

53. Nutter, F. W., Jr. 1990. Remote sensing and image analysis for crop loss assessment. Pages 93-105 in: Crop Loss Assessment in Rice. International Rice Research Institute, Los Banos, Philippines.

54. Nutter, F. W., Jr. 1997. Quantifying the temporal dynamics of plant virus epidemics: A review. Crop Prot. 16:603-618.

55. Nutter, F. W., Jr., and Gaunt, R. E. 1996. Recent developments in methods for assessing disease losses in forage/pasture crops. Pages 93-118 in: Pasture and Forage Crop Pathology. S. Chakraborty, K. T. Leath, R. A. Skipp, G. A. Pederson, R. A. Bray, G. C. M. Latch, and F. W. Nutter, Jr., eds. American Society of Agronomy, Crop Science Society of America, and Soil Science Society of America, Madison, WI.

56. O’Malley, T. B. 2007. Seed transmission studies of Phoma ligulicola. B. Appl. Sc. (Hons) thesis. University of Tasmania, Burnie, Tasmania, Australia.

57. Parlevliet, J. E. 1971. Root knot nematodes, their influence on the yield components of pyrethrum and their control. Acta Hortic. 21:201205.

58. Parlevliet, J. E., and Brewer, J. G. 1971. The botany, agronomy and breeding of pyrethrum (Chrysanthemum cinearariefolium Vis.) in Kenya. Report of the Ministry of Agriculture, Molo, Kenya.

59. Peregrine, W. T. H., and Watson, D. R. W. 1964. Annual Report of the Plant Pathology Section, Department of Agriculture, Tangan- yika.

60. Pethybridge, S. J., Esker, P., Dixon, P., Hay, F., Groom, T., Wilson, C., and Nutter, F. W., Jr. 2007. Quantifying loss caused by ray blight disease in Tasmanian pyrethrum fields. Plant Dis. 91:1116-1121.

61. Pethybridge, S. J., Esker, P., Hay, F., Wilson, C., and Nutter, F. W., Jr. 2005. Spatiotemporal description of epidemics caused by Phoma ligulicola in Tasmanian pyrethrum fields. Phytopathology 95:648-658.

62. Pethybridge, S. J., and Hay, F. S. 2001. Influence of Phoma ligulicola on yield and site factors on disease development in Tasmanian pyrethrum crops. Aust. Plant Pathol. 30:17-20.

63. Pethybridge, S. J., and Hay, F. S. 2007. Host range of Phoma ligulicola isolates causing ray blight disease in Tasmanian pyrethrum fields. (Abstr.) Phytopathology 97:S92.

64. Pethybridge, S. J., Hay, F. S., Clarkson, R. A., Groom, T., and Wilson, C. R. Host range of Australian Phoma ligulicola var. inoxydablis isolates from pyrethrum. J. Phytopathol. In press.

65. Pethybridge, S. J., Hay, F. S., Esker, P. D., Groom, T., Wilson, C. R., and Nutter, F. W., Jr. 2008. Visual and radiometric assessments for yield losses caused by ray blight in pyrethrum. Crop Sci. 48:343-352.

66. Pethybridge, S. J., Hay, F., Esker, P., Wilson, C., and Nutter, F. W., Jr. 2007. Use of a multispectral radiometer for noninvasive assessments of foliar disease caused by ray blight in pyrethrum. Plant Dis. 91:1397-1406.

67. Pethybridge, S. J., Hay, F. S., and Groom, T. 2003. Seasonal fluctuations in fungi associated with pyrethrum foliage in Tasmania. Aust. Plant Pathol. 32:223-230.

68. Pethybridge, S. J., Hay, F. S., Groom, T., and Wilson, C. R. 2008. Improving fungicidebased management of ray blight disease in Tasmanian pyrethrum fields. Plant Dis. 92:887895.

69. Pethybridge, S. J., Hay, F., Jones, S., Wilson, C., and Groom, T. 2006. Seedborne infection of pyrethrum by Phoma ligulicola. Plant Dis. 90:891-897.

70. Pethybridge, S. J., Hay, F. S., and Wilson, C. R. 2004. Pathogenicity of fungi commonly isolated from foliar disease in Tasmanian pyrethrum fields. Aust. Plant Pathol. 33:441-444.

71. Pethybridge, S. J., Hay, F. S., Wilson, C. R., and Groom, T. 2005. Development of a fungicide-based management strategy for foliar disease caused by Phoma ligulicola in Tasmanian pyrethrum fields. Plant Dis. 89:1114-1120.

72. Pethybridge, S. J., Jones, S. J., and Hay, F. S. 2007. A new foliar disease of pyrethrum caused by Microsphaeropsis sp. (Abstr.) Phytopathology 97:S92.

73. Pethybridge, S. J., Jones, S. J., Shivas, R. G., Hay, F. S., Wilson, C. R., and Groom, T. Tan spot: A new disease of pyrethrum caused by Microsphaeropsis tanaceti sp. nov. Plant Pathol. In press.

74. Pethybridge, S. J., Scott, J. B., and Hay, F. S. 2004. Genetic relationships among isolates of Phoma ligulicola from pyrethrum and chrysanthemum based on ITS sequences and its detection by PCR. Aust. Plant Pathol. 33:173-181.

75. Pethybridge, S. J., and Wilson, C. R. 1998. Confirmation of ray blight disease of pyrethrum in Australia. Aust. Plant Pathol. 27:45-48.

76. Pethybridge, S. J., and Wilson, C. R. 2004. A survey for viruses and a viroid in Tasmanian pyrethrum crops. Aust. Plant Pathol. 33:301303.

77. Punithalingam, E. 1980. Didymella chrysanthemi. CMI Descriptions of Pathogenic Fungi and Bacteria. No. 662. Kew, England.

78. Purdy, L. H. 1979. Sclerotinia sclerotiorum: History, diseases and symptomatology, host range, geographic distribution, and impact. Phytopathology 69:875-880.
79. Raikes, C., and Burpee, L. L. 1998. Use of multispectral radiometry for assessment of Rhizoctonia blight in creeping bentgrass. Phytopathology 88:446-449.

80. Rawnsley, R. P., Lane, P. A., Brown, P. H., and Groom, T. 2006. Occurrence and severity of the weeds Anthriscus caucalis and Torilis nodosa in pyrethrum. Aust. J. Exp. Agric. 46:711-716.

81. Robinson, R. A. 1963. Diseases of pyrethrum in Kenya. East Afr. Agric. For. J. (January) 164-167.

82. Rodgers, E. 2003. Diffusion of Innovations. 5th ed. Free Press, New York.

83. Safir, G. R., Svits, G. H., and Ellingboe, A. H. 1972. Spectral reflectance and transmittance of corn leaves infected with Helminthosporium maydis. Phytopathology 62:1210-1213.

84. Scheinpflug, H. 1988. History of DMI fungicides and monitoring for resistance. Pages 77 78 in: Fungicide Resistance in North America. American Phytopathological Society, St. Paul $\mathrm{MN}$

85. Shaw, D. E. 1984. Micro-organisms in Papua New Guinea. Department of Primary Industry, Res. Bull. No. 33, Port Moresby, Papua New Guinea.

86. Srinath, K. V., and Sarwar, M. 1965. Alternaria blight of pyrethrum. Curr. Sci. 34:295.

87. Steadman, J. R. 1979. Control of plant diseases caused by Sclerotinia species. Phytopathology 69:904-907.

88. Steddom, K., Bredehoeft, M. W., Khan, M., and Rush, C. M. 2005. Comparison of visual and multispectral radiometric disease evaluations of Cercospora leaf spot of sugar beet Plant Dis. 89:153-158.

89. Strider, D. L. 1994. Chrysanthemum diseases: A grower's guide. Rev. Chapingo Ser. Hortic $1: 131-135$.

90. Tammen, J. 1963. Stemphylium ray speck of chrysanthemum. Phytopathology 53:749-754.

91. Turechek, W. W., and Madden, L. V. 1999. Spatial pattern analysis of strawberry leaf blight in perennial production systems. Phytopathology 89:421-433.

92. Turechek, W. W., and Madden, L. V. 1999. Spatial pattern analysis and sequential sampling for the incidence of leaf spot on strawberry in Ohio. Plant Dis. 83:992-1000.

93. Van der Aa, H. A., Noordeloos, M. E., and De Gruyter, J. 1990. Species concepts in some larger genera of the Coelomycetes. Stud. Mycol. 32:3-19.

94. Wainaina, J. M. G. 1995. Pyrethrum flowers Production in Africa. Pages 50-54 in: Pyrethrum Flowers: Chemistry, Toxicology and Uses. J. E. Casida and G. B. Quistad, eds. Oxford University Press, New York.

95. Wilson, C. R. 1998. Incidence of weed reservoirs and vectors of tomato spotted wilt tospovirus on southern Tasmania lettuce farms. Plant Pathol. 47:171-176.

96. Wilson, C. R. 1999. Susceptibility of pyrethrum and opium poppy to tomato spotted wilt tospovirus infection. Aust. Plant Pathol 28:333-335.

97. Wilson, J. M., and Moran, J. R. 1983. The incidence of chrysanthemum virus $\mathrm{B}$, tomato aspermy virus and tomato spotted wilt virus in commercial flower crops in Victoria. Aust. Plant Pathol. 12:17-23.

98. Wolfe, M. S. 1985. The current status and prospects of multiline cultivars and variety mixtures for disease control. Annu. Rev. Phytopathol. 23:251-273

99. Zito, S. W. 1994. Chrysanthemum cinerariaefolium (pyrethrum): In vitro culture and the production of pyrethrins and other secondary metabolies. Biotech. Agric. For. 26:56-67.

100. Zito, S. W., Zieg, R. G., and Staba, E. J. 1983 Distribution of pyrethrins in oil glands and leaf tissue of Chrysanthemum cinerariaefolium. J. Med. Plant Res. 47:205-207. 


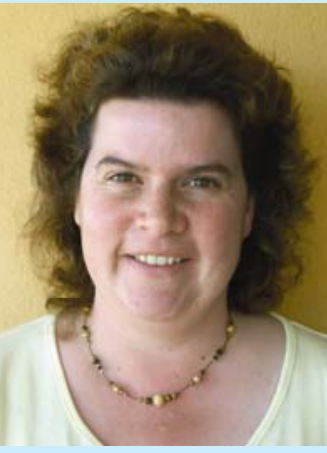

Sarah J. Pethybridge

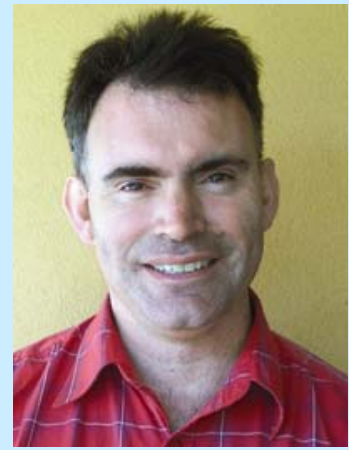

Frank S. Hay

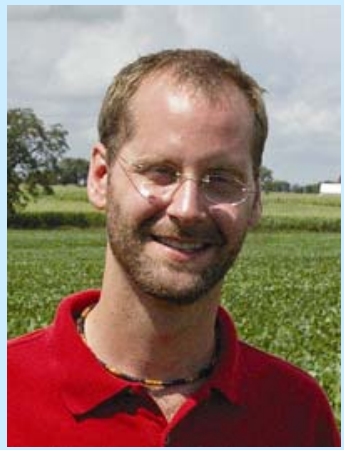

Paul D. Esker

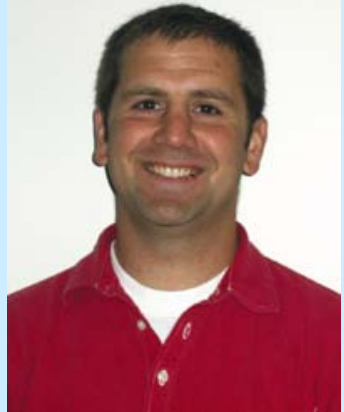

David H. Gent

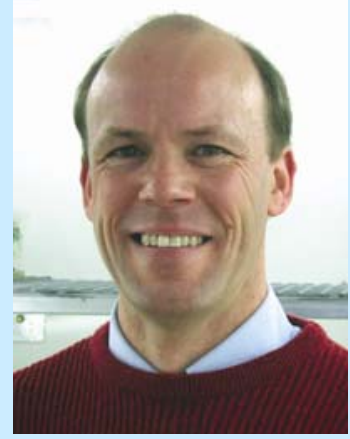

Calum R. Wilson

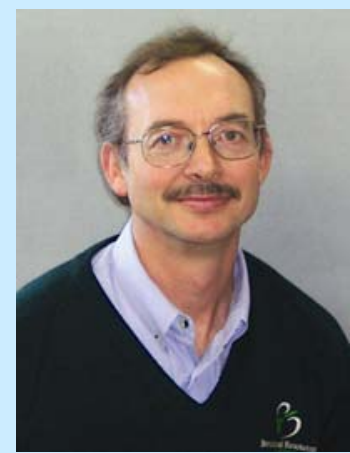

Tim Groom

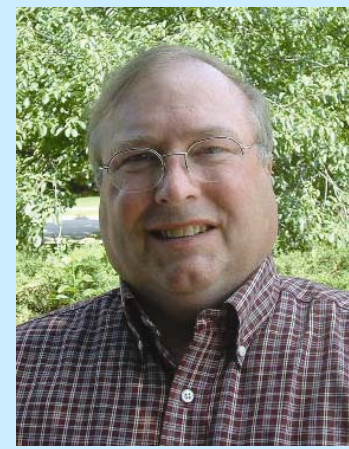

Forrest W. Nutter, Jr.
Dr. Pethybridge is a research plant pathologist with the Tasmanian Institute of Agricultural Research (TIAR) at the University of Tasmania's Cradle Coast campus in Burnie, Tasmania, Australia. She completed her undergraduate degree in Agricultural Science with First Class Honors and Doctor of Philosophy degree in plant pathology at the University of Tasmania in Hobart. She has been working on pyrethrum diseases in Tasmania since 1995. Her research program focuses on the development of cost-effective management strategies for diseases affecting pyrethrum, with emphasis on ray blight, Sclerotinia flower blight, and Botrytis flower blight.

Dr. Hay is the leader of the Vegetable Research Centre within TIAR, and is based at the University of Tasmania's Cradle Coast campus in Burnie. He completed his Bachelor of Horticultural Science degree with First Class Honors and Doctor of Philosophy degree in plant pathology at Lincoln University in Christchurch, New Zealand. Dr. Hay's research program focuses on the integrated management of a variety of diseases of vegetables and pyrethrum, including nematodes.

Dr. Esker is an assistant professor and extension field crops plant pathologist within the Department of Plant Pathology at the University of Wisconsin in Madison. Dr. Esker received a degree in genetics and bacteriology from the University of Wisconsin, and a Master of Science degree from lowa State University in plant pathology. He received his Doctor of Philosophy degree from lowa State University with a co-major in plant pathology and statistics. His program emphasizes increasing the understanding of how plant pathogens affect field crop production through a systems approach.

Dr. Gent is a research plant pathologist with the United States Department of Agriculture - Agricultural Research Service and courtesy assistant professor with the Department of Botany and Plant Pathology, Oregon State University, in Corvallis, OR. He received his Bachelor of Science degree from Oregon State University, and his Master of Science and Doctor of Philosophy degrees from Colorado State University. His program focuses on the integrated management of hop diseases, focusing on the epidemiology of downy and powdery mildews, and interactions with the management of arthropod pests.

Dr. Wilson is an associate professor of plant pathology within TIAR, and is located at the University of Tasmania's New Town Research Laboratories in Hobart. Dr. Wilson obtained his Bachelor of Science with Honors and Master of Science with Distinction from the University of Canterbury in Christchurch, New Zealand, and his Doctor of Philosophy degree from the University of Western Australia in Perth. His research portfolio is diverse, with work across a range of plant pathogens and hosts, but focuses on host-pathogen interactions, resistance mechanisms and genetics, epidemiology, and disease management.

Mr. Groom is manager of agricultural businesses at Botanical Resources Australia Pty. Ltd., in Ulverstone, Tasmania. He was awarded a Bachelor of Agricultural Science with Honors from the University of Tasmania, and a Graduate Diploma in Agriculture (Nutrition) from Hawkesbury Agricultural College. In this position, he focuses his expertise toward the conduct and management of research programs related to business activities of Botanical Resources Australia Pty. Ltd., which is the major Australian pyrethrum grower and producer of over $30 \%$ of the world's supply.

Dr. Nutter is a plant disease epidemiologist in the Department of Plant Pathology at lowa State University. He received his Bachelor of Science from the University of Maryland, a Master of Science from the University of New Hampshire, and a Doctor of Philosophy degree from North Dakota State University in plant pathology with a minor in plant breeding and statistics. His research program focuses on quantitative epidemiology, crop loss modeling, and the use of remote sensing and geographic information systems in disease risk assessment. In 1998, he received the American Phytopathological Society (APS) Foundation Genesis Award for innovative teaching involving computerbased learning and in 1994 the Ciba-Geigy (Syngenta) Award from APS in recognition of his significant contributions to plant disease epidemiology and management. 